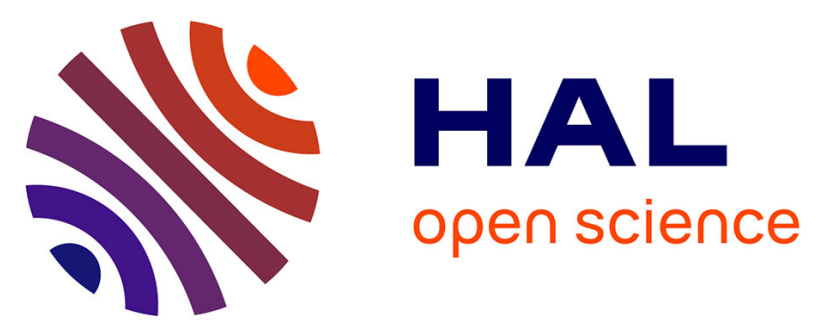

\title{
Expression and nutritional regulation of Stearoyl-CoA desaturase genes in the ruminant mammary gland: relationship with milk fatty acid composition
}

Laurence Bernard, Christine Leroux, Yves Y. Chilliard

\section{To cite this version:}

Laurence Bernard, Christine Leroux, Yves Y. Chilliard. Expression and nutritional regulation of Stearoyl-CoA desaturase genes in the ruminant mammary gland: relationship with milk fatty acid composition. Stearoyl-CoA desaturase genes in lipid metabolism, Springer Science+Business Media, 239 p., 2013, 978-1-4614-7968-0. 10.1007/978-1-4614-7969-7_13 . hal-02810768

\section{HAL Id: hal-02810768 \\ https: / hal.inrae.fr/hal-02810768}

Submitted on 6 Jun 2020

HAL is a multi-disciplinary open access archive for the deposit and dissemination of scientific research documents, whether they are published or not. The documents may come from teaching and research institutions in France or abroad, or from public or private research centers.
L'archive ouverte pluridisciplinaire HAL, est destinée au dépôt et à la diffusion de documents scientifiques de niveau recherche, publiés ou non, émanant des établissements d'enseignement et de recherche français ou étrangers, des laboratoires publics ou privés. 


\title{
Chapter 13 \\ Expression and Nutritional Regulation of Stearoyl-CoA Desaturase Genes in the Ruminant Mammary Gland: Relationship with Milk Fatty Acid Composition
}

\author{
L. Bernard, C. Leroux, and Y. Chilliard
}

\section{Introduction}

In lactating ruminants, stearoyl-CoA desaturase $(S C D)$ gene expression in the mammary gland focused particular attention due to its implication in milk technological and nutritional qualities for human consumers. Indeed, the mammary enzyme SCD or $\triangle 9$-desaturase by introducing a cis double bond between carbons 9 and 10 of the fatty acids (FA) has a key role in the synthesis of milk monounsaturated FA and specific conjugated linoleic acid (CLA) isomers only found in ruminant products. Then, in milk, about $60 \%$ of oleic (cis-9-18:1; a major milk FA), $50-56 \%$ of palmitoleic (cis-9-16:1), $90 \%$ of myristoleic (cis-9-14:1), and $>60 \%$ of the major isomer of CLA (cis-9, trans-11-18:2 or rumenic acid) originate from mammary gland synthesis by the action of SCD enzyme on circulating stearic (18:0), palmitic (16:0), myristic (14:0), and vaccenic acids (trans-11-18:1), respectively. This action is very important due to the impact of milk fat concentration and FA profile in determining milk nutritional quality. Indeed, certain saturated FA (mainly 12:0, 14:0 and 16:0) and trans-FA are considered to exert negative effects when consumed in excess, whereas others (4:0, anteiso-15:0, cis-9-18:1, 18:3n-3, and some CLA isomers) have potentially positive effects on human health (Parodi 2005; Shingfield et al. 2008b). For example, cis-9, trans-11-18:2, the major isomer of CLA in ruminant milk, exhibits anticarcinogenic and antiatherogenic (Wahle et al. 2004) properties in animal models. Thus, by contributing to the synthesis of FA that are beneficial from the point of view of human nutrition, e.g., cis-9, trans11-CLA and to a lesser extent cis-9-18:1, SCD contribute to improve the nutritional quality of milk fat. In addition, by introducing a cis-9 double bond to FA,

\footnotetext{
L. Bernard $(\bowtie) \bullet$ C. Leroux $\bullet$ Y. Chilliard

INRA, UMR1213 Herbivores, Saint-Genès-Champanelle 63122, France

Clermont Université, VetAgro Sup, UMR Herbivores, Clermont-Ferrand, BP 10448 63000, France

e-mail: Laurence.Bernard@clermont.inra.fr
} 
SCD contribute to lower the milk fat melting point (Parodi 1982). Differences in mammary gland level of SCD protein may help in explaining the substantial variation in milk fat content of these fatty acids and thus studies on the regulation of SCD activity and gene expression in the mammary gland have focused major interest in the last decades. Overall, different experiments have been conducted in dairy ruminants for studying the effect of nutrition on milk fat secretion and composition in relation with the regulation of mammary lipogenic gene expression and in particular of $S C D$ gene. For this purpose measures were performed at the level of the mammary tissue and milk fat and different variables were determined as follows: (1) mammary $S C D$ transcript abundance (SCD1 and SCD5 mRNA), (2) mammary SCD activity, (3) the in vivo $\Delta$ 9-desaturation by a chemical tracer technique, and (4) milk FA $\Delta$-9 desaturation ratios (4 milk ratios of the pairs of FA that represent a product/substrate relationship for SCD: cis-9-14:1/14:0, cis-9-16:1/16:0, cis-9-18:1/18:0, cis-9, trans-11-CLA/ trans-11-18:1), which are less invasive indicators commonly used as a proxy for $\Delta 9$-desaturase activity due to the difficulty in measuring the activity.

This chapter reviews the present knowledge on $S C D$ genes expression in the ruminant mammary gland, in particular, the known effects of nutritional factors in relation with milk FA composition and the effect of specific FA studied using in vitro models. In addition, the known or putative molecular mechanisms underlying these regulations are presented.

\section{Functions of SCD in the Mammary Gland of Ruminant}

Milk fat is composed of ca. $98 \%$ of triglycerides (TG) whose FA have a dual origin: (1) either they are de novo synthesized in the mammary gland (Fig. 13.1) from circulating acetate and 3-hydroxybutyrate, produced by ruminal fermentation of carbohydrates and by rumen epithelium from absorbed butyrate, respectively, thus resulting in short and medium chain FA (C4:0 to C16:0) that represent 40-50\% of the FA secreted in milk or (2) they are imported from the plasma, where they are either released by the enzyme lipoprotein lipase (LPL) (Barber et al. 1997) from triglycerides circulating in chylomicra or very low density lipoprotein (VLDL), or derived from the plasma non-esterified fatty acids (NEFA) that circulate bound to albumin, for long-chain FA ( $\geq \mathrm{C} 18)$, as well as ca. one half of the 16:0 and very low amount of 14:0 depending on the diet composition. Whatever their origin, these FA may be desaturated by SCD, but not elongated, in the secretory mammary epithelial cells (MECs) (Chilliard et al. 2000). In lactating ruminants, mammary glands have high levels of SCD mRNA (Ward et al. 1998; Bernard et al. 2005a) and activity (Bickerstaffe and Annison 1970; Kinsella 1970; McDonald and Kinsella 1973; Bernard et al. 2005b, 2009a, b). The protein SCD is located in the endoplasmic reticulum and catalyses the $\Delta-9$ desaturation, introducing a cis double bond, of a spectrum of fatty acyl-CoA substrates, mainly from C14 to C19. This reaction requires $\mathrm{NADH}$, oxygen, and an electron transport sequence comprising NADHcytochrome $b 5$ reductase, cytochrome $b 5$, and SCD. The preferred substrate of SCD 


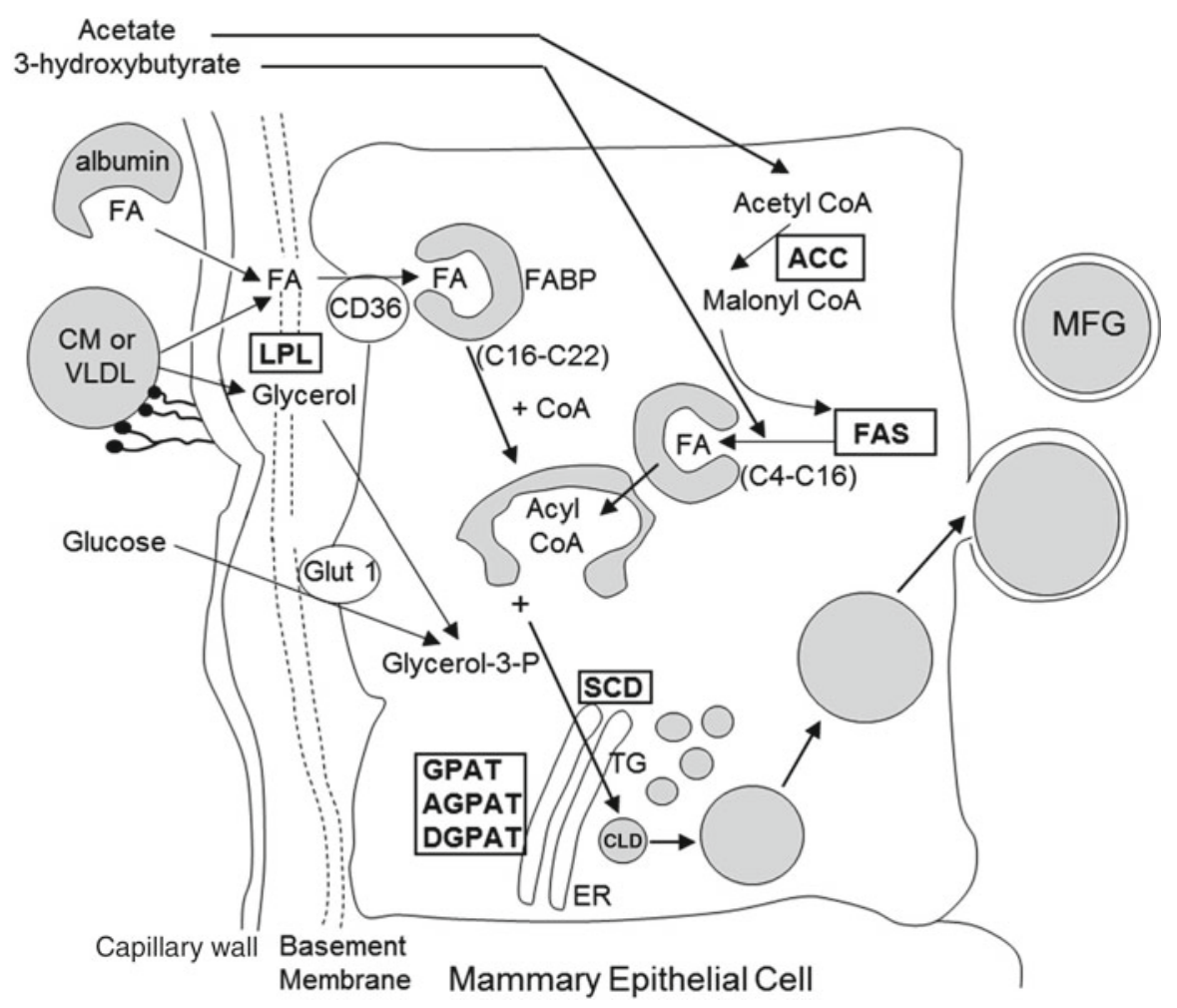

Fig. 13.1 Milk fat synthesis in the ruminant mammary epithelial cell (from Bernard et al. 2008). $A C C$ acetyl CoA carboxylase, AGPAT acyl glycerol phosphate acyl transferase, CD36 cluster of differentiation 36, $C L D$ cytoplasmic lipid droplet, $C O A$ coenzyme A, $C M$ chylomicron, DGAT diacyl glycerol acyl transferase, $E R$ endoplasmic reticulum, $F A$ fatty acid, $F A B P$ fatty acid binding protein, $F A S$ fatty acid synthase, Glut 1 glucose transporter1, GPAT glycerol-3 phosphate acyl transferase, $L P L$ lipoprotein lipase, $M F G$ milk fat globule, $S C D$ stearoyl-CoA desaturase, $T G$ triglyceride, $V L D L$ very low density lipoprotein

is stearic acid leading to the synthesis of oleic acid, the major unsaturated fatty acid found in milk triacylglycerol. In bovine, a number of other saturated acyl-CoA also serve as substrates for SCD including 10:0, 12:0, 14:0, 15:0, and 17:0 (Shingfield et al. 2008b) as well as trans-FA such as trans-7- and trans-12-18:1 (Palmquist et al. 2005; Shingfield et al. 2007). Thus, trans-7, cis-9-18:2 (CLA) in milk originates almost exclusively from the action of $\Delta 9$-desaturase on trans-7-18:1 in the mammary gland (Corl et al. 2002). In addition, recent results also suggest that conjugated linolenic acids (CLnA) such as cis-9, trans-11, trans-13-18:3, and cis-9, trans-11, trans-15-18:3 in milk are synthesized endogenously via the action of $\Delta 9$-desaturase on trans-11, trans-13-18:2, and trans-11, trans-15-18:2 in the mammary gland, respectively (Lerch et al. 2012). All these trans-18:1 or trans-18:2 FA that may serve as substrate for mammary SCD originate from the ruminal biohydrogenation of the major FA found in the diet delivered to ruminant. 
The unsaturation of fatty acid chain is a major determinant of the melting temperature of triglycerides (TG), thus determining the fluidity of milk fat. The fundamental function of mammary SCD in maintaining the physical properties of TG is even increased in ruminants due to the large biohydrogenation processes of dietary PUFA that occur in the rumen which led to the synthesis of saturated FA (mainly 18:0) as well as of numerous intermediates, in particular, trans-FA (Shingfield et al. 2010) that could be further taken up by the mammary gland. Indeed, whereas it is well established that endogenous synthesis of cis-9-18:1 via the action of SCD on 18:0 in the mammary gland is an important point of regulation in milk TG synthesis and maintenance of milk fat fluidity, the presence of a cisor trans-double bond as well as of short-chain FA and saturated FA also intervene in the maintenance of milk fat fluidity (Chilliard et al. 2000). In this way, a metaanalysis of milk FA yield in relation to duodenal flows (Glasser et al. 2008) showed an interdependence of $\mathrm{C} 18$ and $\mathrm{C} 4$ to $\mathrm{C} 16$ probably due to the esterification step of milk fat synthesis, which involves a putative balance between long-chain and de novo synthesized FA to maintain milk TG fluidity. In the same way it was proposed that, under certain dietary conditions, decreases in the availability of 18:0 for endogenous synthesis of cis-9-18:1 combined with an increase in trans-18:1 at the mammary gland could be a possible mechanism to explain part of the decrease in milk fat secretion (Loor et al. 2005a; Gama et al. 2008). Thus, the ability to maintain milk fat melting point within physiological values could play a role in the regulation of milk fat secretion when milk FA composition varies, for example, in response to feeding factors. In this context, the hypothesis of a contribution of milk fat fluidity to the regulation of milk fat secretion has been proposed (Timmen and Patton 1988; Chilliard et al. 2000) and was confirmed recently in a meta-analysis on cow, goat, and ewe milk FA composition and estimated melting point (Toral et al. 2013a). In addition, studies in goats (Chilliard et al. 2006) on the effect of the CSN1S1 genotype on milk FA profile have reported higher $\Delta 9$-desaturation ratios in defective vs. high genotypes suggesting higher expression of SCD in defective genotypes in which the synthesis of short-chain FA is lower. This result led to the hypothesis that higher SCD expression could compensate for the concomitant decrease in short-chain FA and thus to maintain the milk fat melting point in defective genotypes.

\section{Characterization of SCD Genes}

Multiple isoforms of $S C D$ have been found in most species examined to date. Some rodent genomes (as mice) contain four $S C D$ isoforms (SCD1-4) with different expression profiles according to tissues. For example, murine $S C D 1$ is expressed predominantly in lipogenic tissues (Ntambi et al. 1988), while SCD2 is preferentially expressed in brain and neuronal tissues (Kaestner et al. 1989), SCD3 is expressed in sebocytes, preputial gland, and Harderian gland (Zheng et al. 2001), and SCD4 expression is restricted to the heart (Miyazaki et al. 2003). Up to now, the genomes of many other species, including chickens, pigs, cows, and humans, have 
been found to contain two $S C D$ isoforms. Then, in humans: $S C D 1$ is highly expressed in adipose tissue and liver while a second $S C D$ gene, termed $S C D 5$, is highly expressed in brain and pancreas (Wang et al. 2005). In addition to tissuespecific expression profile, there is evidence to suggest that some SCD protein isoforms may differ in their preferred substrate specificity. For example, murine SCD1, SCD2, and SCD4 have been shown to desaturate both palmitoyl-CoA and stearoyl-CoA, while murine SCD3 desaturates palmitoyl-CoA but not stearoyl-CoA (Miyazaki et al. 2006). The tissue and substrate specificity of SCD isoforms suggests that each may have a distinct physiological role.

In ruminants earlier studies reported only one $S C D$ gene, generating a transcript of $5 \mathrm{~kb}$ in size which was characterized in sheep (Ward et al. 1998), cows (Chung et al. 2000), and goat (Bernard et al. 2001). When compared, the coding region of the caprine $S C D$ mRNA shares $98,95,90$, and $86 \%$ identity with the ovine, bovine, porcine, and human $S C D 1$ mRNAs, respectively. This $S C D$ isoform was highly expressed in lipogenic tissues, adipose tissue, and the lactating mammary gland and was recently renamed $S C D 1$ since the discovery of the $S C D 5$ isoform characterized in ruminant species (Lengi and Corl 2007, 2008). In these species SCD5 is mainly expressed in the brain (Lengi and Corl 2008). In addition to $S C D I$ a significant expression of $S C D 5$ was reported in the lactating mammary gland in cows (Gervais et al. 2009; Jacobs et al. 2011) and goats (Bernard et al. 2010) with probably different regulation for these two isoforms (Gervais et al. 2009; Jacobs et al. 2011). However, both the regulation of the expression and the contribution of SCD5 isoform to FA $\Delta-9$ desaturation process are still unknown.

$S C D 1$ transcript in goat presents an unusually long $(3.8 \mathrm{~kb}) 3^{\prime}$-UTR sequence which derives from a single exon (Bernard et al. 2001), as observed for human (Zhang et al. 1999), rat (Mihara 1990), and mouse (Ntambi et al. 1988). In the caprine, the $3^{\prime}$-UTR is characterized by the presence of several AU-rich elements as observed in the 3'-UTR region of mouse (Kaestner et al. 1989; Sessler et al. 1996), rat (Thiede and Strittmatter 1985; Mihara 1990), and human (Zhang et al. 1999) SCDI transcripts, which could be mRNA destabilization sequences as suggested by Sessler et al. (1996). These AU-rich elements have been shown to play active roles in the mRNA degradation (Vakalopoulou et al. 1991) which is responsible for their turnover. In addition, these motifs could be possible targets of polyunsaturated fatty acids effects on $S C D$ mRNA, as proposed by Ntambi (1999) for $S C D 1$ and $S C D 2$ mRNA in mouse adipocytes. Otherwise, SCD5 transcript in bovine and ovine was of $2.6 \mathrm{~kb}$ in length (Lengi and Corl 2007, 2008) with a 3'UTR corresponding to half the mRNA length.

SCD1 gene was localized on bovine and caprine chromosomes 26q21 and on ovine chromosome 22q21 (Bernard et al. 2001), and SCD5 was localized on bovine chromosome 6 (Lengi and Corl 2007) and on ovine chromosome 6 (Lengi and Corl 2008). In caprine $S C D 1$ gene spans about $15 \mathrm{~kb}$ and has six exons varying in size from 131 (third exon) to 4,047 (sixth exon) bp, and five introns varying in size from 600 to $3,700 \mathrm{bp}$ (Bernard et al. 2001; Fig. 13.2). This structural organization is similar to SCD1 gene reported in human (Zhang et al. 1999) and rodents (Ntambi et al. 1988; Kaestner et al. 1989; Mihara 1990). The genomic structure of bovine 


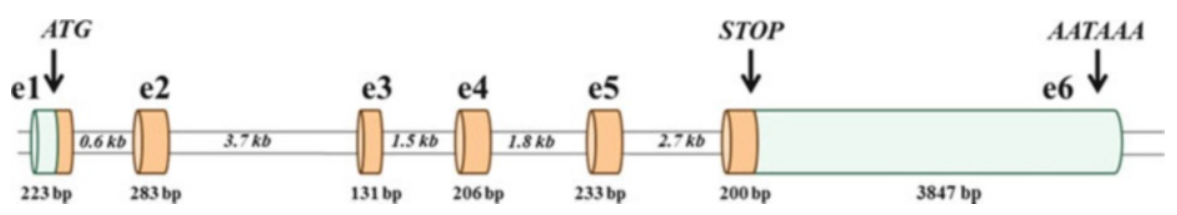

Fig. 13.2 Structural organization of the caprine SCD1 transcription unit. Overall structural organization of the caprine SCD1 gene deduced from PCR analysis. Open bars represent introns and exons are depicted by large, green (UTR) or orange (TR) boxes (from Bernard et al. 2001)

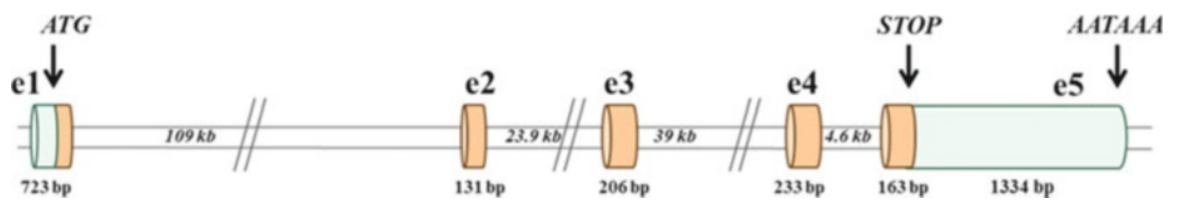

Fig. 13.3 Structural organization of the bovine SCD5 transcription unit. Overall structural organization of the bovine SCD5 gene adapted from Lengi and Corl (2007). Open bars represent introns and exons are depicted by large, green (UTR) or orange (TR) boxes

SCD5 deduced from known bovine genomic DNA sequence showed that SCD5 is organized into five exons and four introns in a fragment tenfold longer than SCD1 spanning more than $175 \mathrm{~kb}$ (Lengi and Corl 2007) and is similar to human SCD5 (Fig. 13.3). Despite the length difference of their genes, the SCD1 and SCD5 encoded proteins are of similar size and are, respectively, composed of 359 and 335 amino acids (AA). Sequence alignment shows $65 \%$ identity between bovine SCD1 and SCD5 at the amino acid level. Both proteins share highly conserved three histidine motifs that are catalytically essential for the desaturase activity. Conversely to SCD1 protein, the N-terminus of the SCD5 protein lacks the conserved PEST (peptide sequence rich in proline, glutamic acid, serine, and threonine). This sequence is present in proteins that have a short intracellular half-time with the hypothesis that PEST sequence acts as a signal peptide for protein degradation (mediated by proteasome or calpaïn). These data suggest that the regulation of SCD1 and SCD5 proteins may differ.

Little is known in ruminant on the molecular mechanisms controlling $S C D$ genes expression (see section "Knowledge on the Signalling Pathways Mediating Nutritional Regulation of SCD Gene Expression in Ruminants"). The promoter region of the bovine $S C D 1$ gene have been studied (Keating et al. 2005) and an area of $36 \mathrm{bp}$ in length was identified as having a critical role in the transcriptional activation and was designated the $S C D$ transcriptional enhancer element (STE). Otherwise, a recent study regarding the possible common transcription factors between bovine $S C D 5$, expressed in brain and nervous tissue, and rodent $S C D 2$, expressed in nervous tissue, demonstrated that early growth response 2 (EGR2) and sterol regulatory element binding protein 1a (SREBP-1a) may bind to the same DNA site in the bovine SCD5 promoter (Lengi and Corl 2012).

In other respects, in order to explain individual differences in milk fat yield and FA composition, in particular in cis- 9 monounsaturated FA, studies in ruminants 
were focused on the genetic variability of the region containing $S C D$ gene. A lot of programs were dedicated to quantitative trait loci (QTL) detection in dairy bovine breeds on milk parameters. In particular, genome-scan for bovine milk fat composition revealed a QTL for the monounsaturated FA and their unsaturation indices on Bos taurus autosome (BTA) 26 corresponding to the chromosome where SCD1 gene is located (Stoop et al. 2009). These authors have strongly suggested that this BTA26 QTL was caused by a mutation in the SCD1 gene. Among the single nucleotide polymorphisms (SNP) detected in $S C D 1$ gene, a nonsynonymous one is located in exon 5 causing a substitution of valine (V) with alanine (A) at position 293 (A293V; Kgwatalala et al. 2007; Schennink et al. 2008). Several studies in different bovine breeds reported significant association between A293V genotypes and milk FA composition with milk of cows carrying the SCD $A A$ genotype having a greater content of cis-9-18:1 and a higher cis-9-14:1/14:0 ratio than did milk of cows carrying the SCD $V V$ genotype (Kgwatalala et al. 2009b; Mele et al. 2007; Conte et al. 2010), whereas others (Moioli et al. 2007) could not confirm this association. These latter authors suggested a role of regulatory factors acting on the promoter region of $S C D$ gene or through activation of the enzyme. In that way, whereas an earlier study on $S C D 1$ promoter has not allowed the detection of SNP (Keating et al. 2005), a more recent study highlighted a SNP $(133 \mathrm{~A}>\mathrm{C})$ creating a new consensus site for the transcription factor SP1 binding site, which could be responsible for a difference in the milk FA desaturation ratio (Pauciullo et al. 2012). Moreover, different SNPs were also detected in intronic or exonic regions without AA substitution in the protein. However, their linkage with milk yield was particularly studied in haplotypic configuration suggesting that they could be used as potential genetic markers to improve milk performance (Alim et al. 2012). For example, SNP haplotypes identified in the $3^{\prime}$ UTR region were reported to be associated with different 10:0 and 12:0 $\Delta-9$ desaturation ratios in bovine milk (Kgwatalala et al. 2009a).

In small ruminants, although less documented, $S C D 1$ gene polymorphism has also been studied. The first characterization of the caprine $S C D 1$ mRNA has revealed a polymorphism involving the deletion of a nucleotide triplet (TGT) in the $3^{\prime}$ UTR region (Bernard et al. 2001). The analyses of this mutation in haplotype-based configuration with two other 3'UTR SNP were suggestively associated with lower milk stearic FA content and with higher percentages of PUFA (Zidi et al. 2010). An in silico analysis of the secondary structure of $S C D 1$ mRNA pointed out the $3 \mathrm{nt}$ deletion as being involved in a considerable change in the secondary structure of the $S C D 1$ mRNA. This change could alter the amount of SCD1 transcripts in MECs (Zidi et al. 2010). In sheep, a QTL analysis for the FA profile showed a QTL for the ratio of rumenic/vaccenic acid in ovine chromosome 22 which coincided with the position of the $S C D$ gene (Carta et al. 2008). However, no association of four SNP previously detected (Garcia-Fernandez et al. 2009) has been observed with the ratio of rumenic/vaccenic acid, whereas a possible effect of the $S C D$ polymorphism on milk fat percentage has been suggested (Garcia-Fernandez et al. 2010).

Due to its recent discovery, the polymorphism of SCD5 gene, located on BTA6, has not been studied to the same extend. A recent study revealed that polymorphisms in the SCD5 gene were among the most representative markers associated 
with unsaturated/saturated FA ratio in milk (Rincon et al. 2012). In this study, two SNP were detected within exon 3 which were, respectively, associated with an increase in saturated FA concentration combined with a decrease in monounsaturated FA, and with a decrease in saturated FA combined with an increase in PUFA. Moreover, an intronic mutation named $\mathrm{G}$ allele was shown to be associated with a decrease in saturated FA/unsaturated FA ratio and an increase in monounsaturated FA and $\Delta-9$ desaturation ratios for 14:0 and trans-11-18:1 content in Holstein milk (Rincon et al. 2012). However, the mechanism by which this mutation acts needs to be clarified.

\section{Regulation of Mammary SCD Genes Expression by Dietary Factors}

\section{Effect of Dietary Factors}

In ruminants, milk FA composition is greatly influenced by feeding factors (Jensen 2002; Dewhurst et al. 2006; Chilliard et al. 2007). Thus, modification of milk fat content and FA composition by dietary manipulation has been investigated and few studies were performed to relate the effect of diet on milk FA profile to mammary lipid metabolism considering the major lipogenic genes, in particular, SCD. The response of $S C D$ gene expression to nutritional changes involves the control of events that could occur at transcriptional (e.g., through transcription factors), posttranscriptional (e.g., such as mRNA stability), translational (e.g., its initiation or through microRNA action), and post-translational (e.g., via turnover or regulation of the activity of the enzymatic protein) levels. However, it is often unclear whether the regulatory factors are the dietary components themselves or their metabolites or hormonal changes produced in response to the nutritional changes. Moreover, in most of the studies, it is difficult to conclude on the level of regulation involved since measurements of SCD mRNA of the enzyme protein content and activity are not studied simultaneously. Only few studies have investigated the role of diet on the regulation of $S C D$ gene expression and activity in ruminants.

As previously mentioned, prior to the characterization of the bovine SCD5 gene (Lengi and Corl 2007), as only one $S C D$ isoform was thought to be present in this species, the gene was simply referred to as $S C D$ for $S C D 1$. The in vivo trials reporting the nutritional regulation of mammary $S C D 1$ and lipogenic genes expression have been carried out in mid-lactation cows and goats and mainly with lipid supplements (Table 13.1). In cows, studies have been primarily realized with diets that induce milk fat depression (MFD). These diets belongs to three types: (1) diets rich in starch without addition of lipid supplements (e.g., high grain/low forage diets), but containing a minimal amount of PUFA in dietary feedstuffs; (2) diets with low level of fiber associated with supplemental PUFA of plant origin; (3) diets associated with dietary supplements of marine oils (fish oils, fish meals, oils from marine 
13 Expression and Nutritional Regulation of Stearoyl-CoA Desaturase Genes...

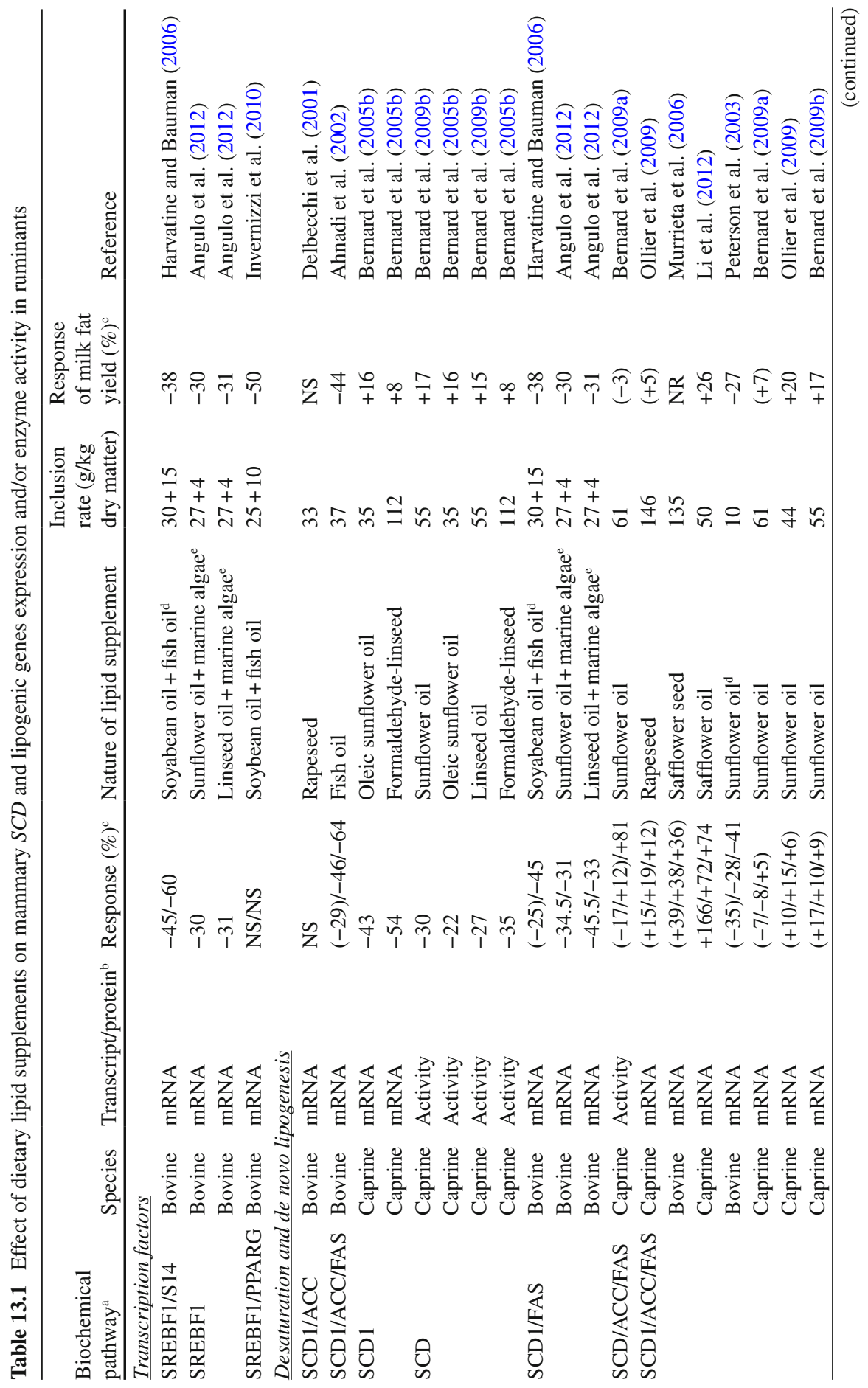




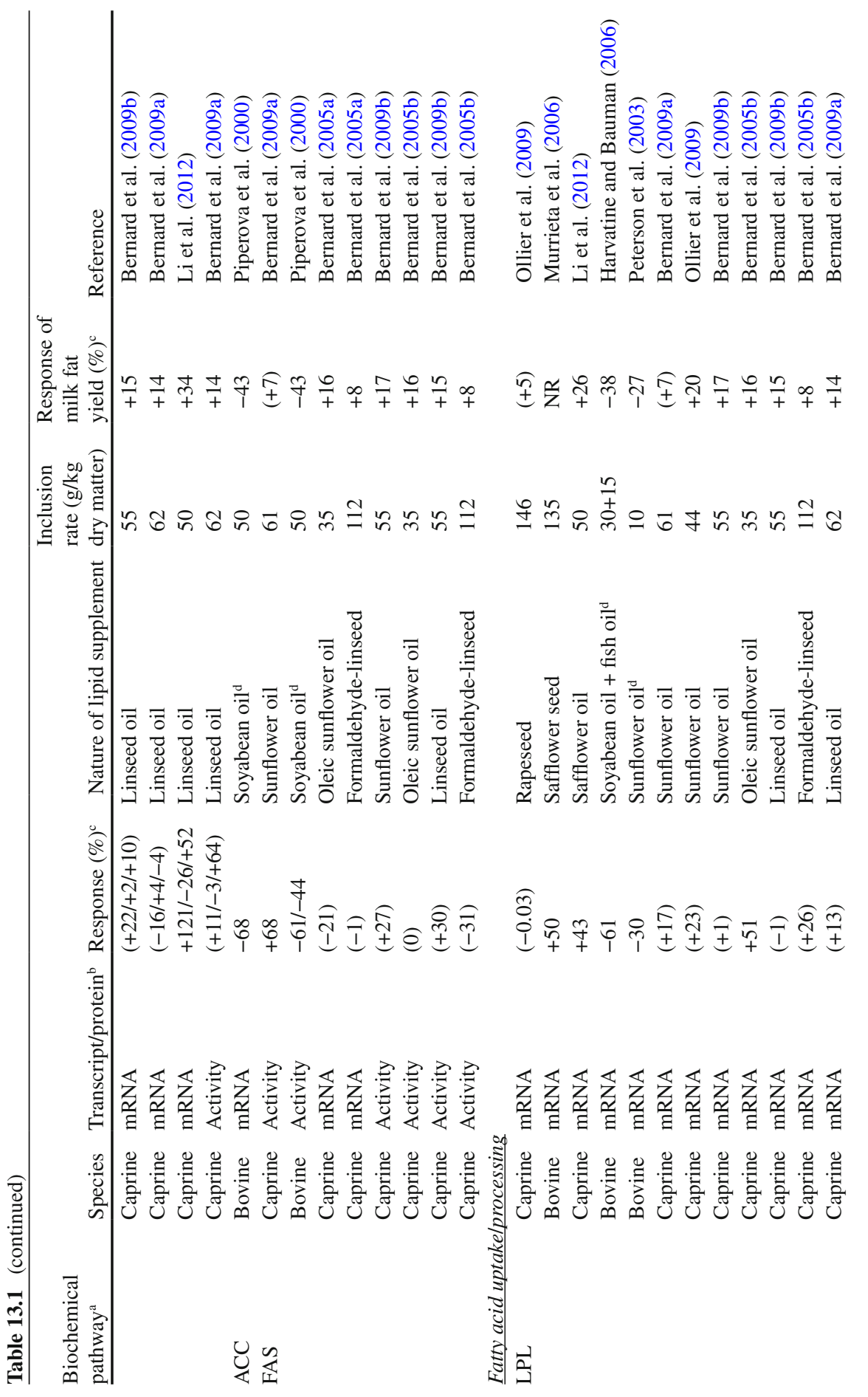




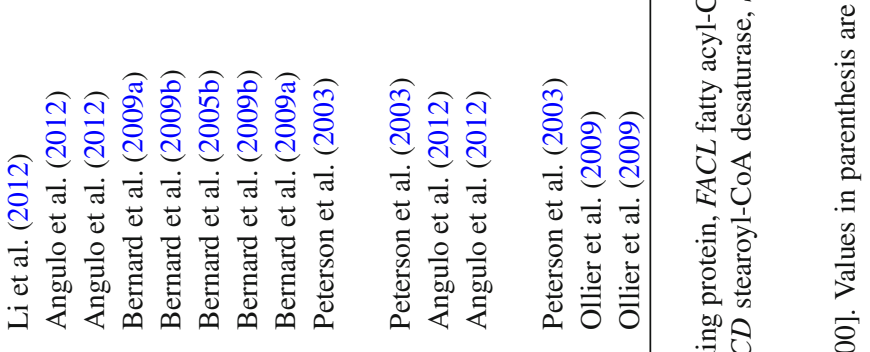

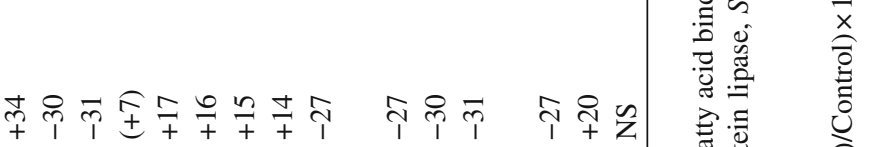

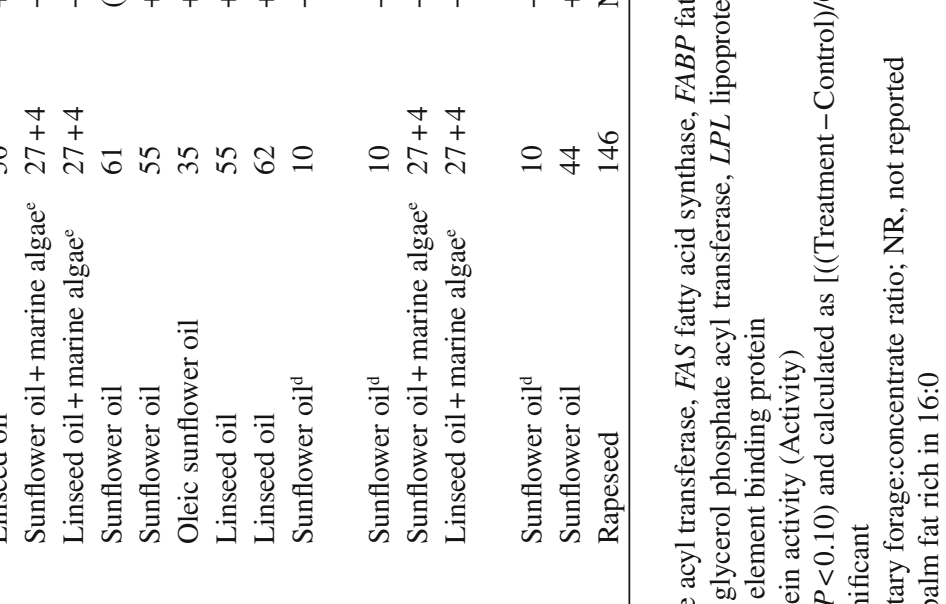

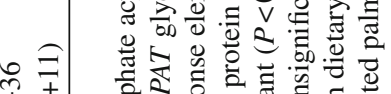

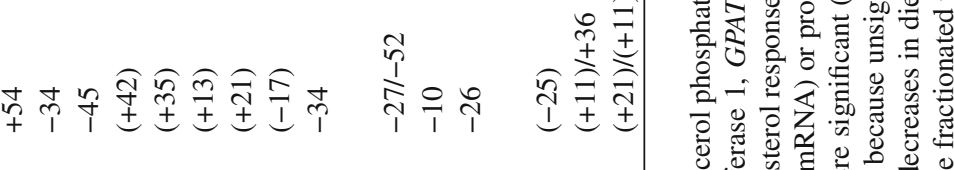

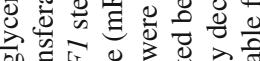

कo

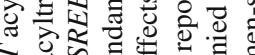

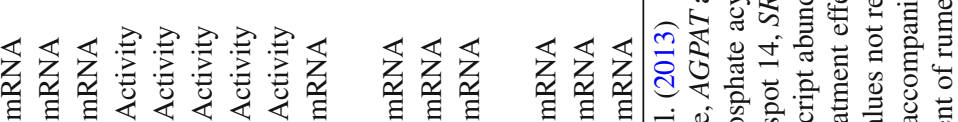

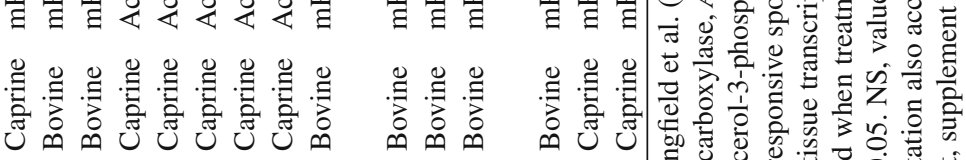

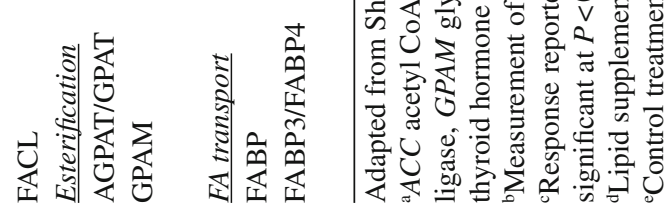


mammals, and/or algae) which induce MFD whatever the level of starch or fiber in the diet. In these dietary conditions, variable responses of mammary SCD1 mRNA abundance have been reported in cows: either no variation with high concentrate diets containing sunflower oil (Peterson et al. 2003) or fish oil and soya bean oil (Harvatine and Bauman 2006); or decreases with diets supplemented with plant oils rich in either $n-3$ or $n-6$ fatty acids (FA) plus docosahexaenoic acid (DHA)-rich algae (Angulo et al. 2012) or with rumen "protected" fish oil (Ahnadi et al. 2002); or surprisingly increases with diets supplemented with fish oil and soya bean oil (Invernizzi et al. 2010). From these studies it is difficult to conclude on the effect of the dietary treatments that induce MFD on SCD1 mRNA abundance and probably that the forage:concentrate ratio and the nature and the level of the PUFA into the diet may intervene to explain such differences. Otherwise, studies in goats have shown that supplementing diets based on grass hay with sunflower-seed oil rich in oleic acid (Bernard et al. 2005b), sunflower-seed oil (18:2 rich), or linseed oil (18:3 rich) decreased SCD activity (Bernard et al. 2009b) but had no effect on mammary SCD1 mRNA abundance, whereas supplementing grass hay-based diets with formaldehyde-treated linseed (FLS) decreased mammary SCD1 mRNA without effect on the SCD activity (Bernard et al. 2005b). In contrast, inclusion of sunflowerseed oil and linseed oil in maize silage-based diets (Bernard et al. 2009a) and of soya beans in lucerne hay-based diets (Bernard et al. 2005a) had no effect on caprine mammary SCD1 mRNA abundance and/or SCD activity. Lastly, in goat, addition of fish oil and starch to a diet containing sunflower-seed oil has no effect on mammary SCD1 and SCD5 mRNA abundances (Bernard et al. 2010).

Overall, these observations (Table 13.1) highlight the importance of interactions between the composition of the basal diet and lipid supplement in the goat with the implication that specific PUFA escaping metabolism in the rumen or specific biohydrogenation intermediates may inhibit SCD activity via transcriptional or post-transcriptional regulatory mechanisms.

In vivo $\Delta-9$ desaturase activity has often been estimated by the milk ratios for the pairs of FA that represent a product/substrate relationship for SCD (Bauman et al. 2001) due to the fact that the in vitro activity assay needs fresh materials and is laborious (Legrand et al. 1997). Moreover, ex vivo activity assay is done in optimal conditions ( $\mathrm{pH}$, substrate, cofactors) and may differ from in vivo conditions. From the few studies in goats reporting mammary SCD activity together with milk fatty acid composition, the response to dietary lipids of the four FA pair ratios that represent a proxy for SCD activity was related to the response of the SCD activity itself (Bernard et al. 2008). In some experiments with goats, lipid supplements in the diet have been shown to reduce milk FA desaturation ratios but have no effect on SCD activity (Bernard et al. 2009a, b, c). However, it was shown that the milk ratio of myristoleic acid to myristic acid (cis-9-14:1/14:0) gave the best estimation for the response of mammary SCD activity (Fig. 13.4; from Bernard et al. 2008), probably due to the fact that almost all the myristoleic acid present in the milk is likely to be synthesized in the mammary gland from de novo synthesis of myristic acid followed by desaturation by SCD. Indeed, 14:0 and 14:1 even less are poorly represented in feedstuffs used for ruminants, including lipid supplements (except for 14:0 

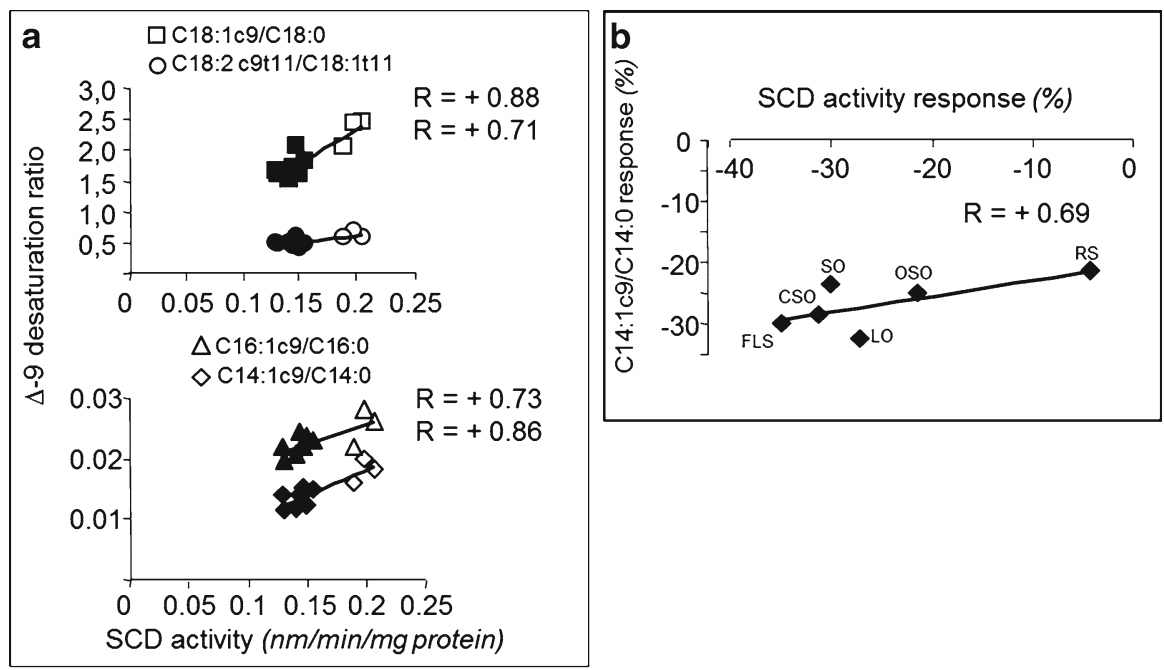

Fig. 13.4 Relationships between milk FA desaturation ratios and stearoyl-CoA desaturase (SCD) activity in 43 goats fed hay-based diet supplemented, or not, with lipids. The lipid supplements were either $3.6 \%$ of lipids from oleic sunflower oil (OSO) or formaldehyde-treated linseed (FLS) (Bernard et al. (2005b)), or $5.8 \%$ lipids from linseed oil (LO) or sunflower oil (SO) (Bernard et al. (2009a)), or $6.5 \%$ whole rapeseed (RS) or $4.5 \%$ of sunflower oil (CSO) (Ollier et al. (2009)) (from Bernard et al. 2008). (a) Results are means of the seven lipid-supplemented groups (black symbols) and the three control groups (white symbols). (b) Relationship between the responses (\% of the control group) of SCD activity and milk cis-9-14:1/14:0 to the six lipid supplements

in specific lipid supplements such as coconut or krabo oils), and the circulating 14:1 in ruminant is very low (Christie 1981). Otherwise, variable proportions of palmitoleic, oleic, and rumenic acids come from absorption from the digestive tract and/or mobilization of body fat reserves. Consequently, the ratios that involve these latter FA are less indicative of SCD activity even though stearoyl-CoA and palmitoyl$\mathrm{CoA}$ are the preferred substrates for SCD. Indeed, activity of SCD was estimated to contribute to approximately $90 \%$ of cis-9-14:1 compared to $50-56 \%$ of cis-9-16:1, $60 \%$ of cis-9-18:1, and $>60 \%$ of cis-9, trans-11-18:2 in bovine milk fat (Enjalbert et al. 1998; Mosley and McGuire 2007; Glasser et al. 2008). Moreover, differential uptake, turnover, and use of different FA of the four pair ratios by the mammary tissue itself may occur.

In other respects, several experiments in goats have provided evidence to support the involvement of post-translational mechanisms in the regulation of SCD activity. Inclusion of cis-9-18:1 enriched sunflower oil (Bernard et al. 2005b), sunflower oil, or linseed oil (Bernard et al. 2009b) in the diet of goats fed grass hay-based diets has been shown to lower mammary SCD activity measured ex vivo without changing mammary SCD1 mRNA abundance. Otherwise, in goats fed maize silage-based diet, addition of plant oils had no effect on mammary SCD1 mRNA or SCD activity (Bernard et al. 2009a). However, in four in vivo studies in goats (Bernard et al. 
2005b, 2009a, b; Ollier et al. 2009), the relationship between the responses of SCD1 mRNA and enzyme activity (means per treatment) to the eight lipid supplements (expressed relative to the control) was relatively weak $(r=0.55)$, which may indicate the existence of putative post-traductional regulatory events. In the same way, a recent study in goats using a proteomic analysis suggested an increased protein expression of PSMA5 (proteasome subunit $\alpha$ type 5) and a higher mRNA abundance of $S C D$ in the mammary tissue following trans-11-18:1 treatment (by intravenous bolus injection) (Jin et al. 2012). SCD is a short-lived integral membrane protein of the endoplasmic reticulum (Oshino and Sato 1972), and PSMA5 as a part of the ubiquitin proteasome system may be involved in constitutive SCD degradation, and thus could play a role in SCD regulation as further suggested in MAC-T cells (Jin et al. 2012).

Otherwise, in order to determine the in vivo SCD metabolic activity, different methods have been developed and used in ruminants, in particular, to estimate the in vivo conversion of stearic to oleic acid or vaccenic to rumenic acid in the mammary gland. These methods include direct methods, by means of a tracer (for example, $\left[1{ }^{-13} \mathrm{C}\right]$ trans-11 18:1; Mosley et al. 2006; Bernard et al. 2010), and indirect methods, through quantification of duodenal and milk FA flows (Shingfield et al. 2007; Glasser et al. 2008) or inhibition of the desaturase system using sterculic acid (Griinari et al. 2000; Corl et al. 2001; Kay et al. 2004; Bichi et al. 2012). Studies using these methods provided clear evidence that the endogenous desaturation of stearic and vaccenic acids are the main sources of milk oleic and rumenic acids, respectively. Indeed, about $80 \%$ (Glasser et al. 2008), 80-84\% (Annison et al. 1974), and $63 \%$ (Bichi et al. 2012) of oleic acid comes from stearic acid, respectively, in cows, goats, and ewes. In the same way, 64-97 \% (Mosley et al. 2006; Glasser et al. 2008), 63-73\% (Bernard et al. 2010), and $74 \%$ (Bichi et al. 2012) of rumenic acid comes from vaccenic acid, respectively, in cows, goats, and ewes. In addition, few of them provided an estimation of stearic or vaccenic acid desaturation in the mammary gland: for stearic acid it was of $59 \%$ (Mosley and McGuire 2007) and $54 \%$ (Glasser et al. 2008) in cows; for vaccenic acid it was of $25.7 \%$ (Mosley et al. 2006), 28.9\% (Shingfield et al. 2007), 19.8\% (Qiu et al. 2004), $21 \%$ (Glasser et al. 2008) in cows and of $31.6 \%$ in goats (Bernard et al. 2010).

\section{Ruminant Species Specificities}

Indirect comparisons from experiments examining in cows and goats the effect of nutrition on milk fatty acid composition outlined several differences in milk cis9-FA and $\triangle-9$ desaturation ratios responses to lipid supplements among these two species (Chilliard et al. 2007). As a large proportion of the cis-9-FA secreted in milk is synthesized endogenously via the action of mammary SCD, differences in their concentration may suggest specificities in mammary SCD regulation among species. Indeed, in experiments with goats fed maize silage- or grassland hay-based supplemented with plant oils (Chilliard et al. 2007; Bernard et al. 2009c), the 
Table 13.2 Effect of inclusion of sunflower oil (rich in cis-9, cis-12-18:2) into a maize silage-based diet on milk fatty acid secretion and composition (including trans-10, cis-12-, trans-10, trans-12-, trans-9, trans-11-CLA) and milk fatty acid desaturation ratio responses in cows and goats

\begin{tabular}{|c|c|c|c|c|}
\hline Species & \multicolumn{2}{|l|}{ Bovine } & \multicolumn{2}{|l|}{ Caprine } \\
\hline Reference & \multicolumn{2}{|c|}{ Roy et al. (2006) } & \multicolumn{2}{|c|}{ Bernard et al. (2009c) } \\
\hline Major forage of the diet & \multicolumn{2}{|c|}{ Maize silage } & \multicolumn{2}{|c|}{ Maize silage } \\
\hline Treatment & Control & Sunflower & Control & Sunflower \\
\hline Oil inclusion rate ( $\mathrm{g} / \mathrm{kg}$ dry matter) & 0 & 52 & 0 & 63 \\
\hline \multicolumn{5}{|l|}{ Diet composition } \\
\hline Concentrate (g/kg dry matter) & 520 & 537 & 612 & 545 \\
\hline Neutral detergent fiber ( $\mathrm{g} / \mathrm{kg}$ dry matter) & 285 & 266 & 310 & 295 \\
\hline \multicolumn{5}{|l|}{ Milk fat content and secretion } \\
\hline Milk fat output (g/d or response) $)^{\mathrm{a}}$ & 1,380 & $(-44.2 \%)$ & 107 & $(+6.5 \%)$ \\
\hline $14: 0(\mathrm{~g} / \mathrm{d}$ or response $)$ & 156.0 & $(-67.5 \%)$ & 12.0 & $(-28.5 \%)$ \\
\hline $18: 0(\mathrm{~g} / \mathrm{d}$ or response $)$ & 111.1 & $(-11.9 \%)$ & 4.9 & $(+96.7 \%)$ \\
\hline trans-10-18:1 (g/d or response) & 5.54 & $(+837 \%)$ & 0.44 & $(+682 \%)$ \\
\hline \multicolumn{5}{|l|}{ Fatty acid (g/100 $\mathrm{g}$ fatty acids) } \\
\hline $10: 0$ & 3.46 & 1.2 & 10.58 & 6.91 \\
\hline 12:0 & 3.94 & 1.65 & 5.72 & 3.12 \\
\hline $14: 0$ & 12.12 & 7.06 & 12.07 & 8.10 \\
\hline $16: 0$ & 32.32 & 18.93 & 29.85 & 18.78 \\
\hline 18:0 & 8.63 & 13.62 & 4.88 & 9.01 \\
\hline trans-10-18:1 & 0.43 & 7.22 & 0.44 & 3.23 \\
\hline trans-10, cis-12-CLA & 0.003 & 0.024 & 0.004 & 0.064 \\
\hline trans-9, trans-11-CLA & 0.006 & 0.008 & 0.015 & 0.059 \\
\hline trans-10, trans-12-CLA & 0.004 & 0.015 & 0.003 & 0.024 \\
\hline \multicolumn{5}{|l|}{ Milk fatty acid desaturation ratios } \\
\hline cis-9-14:1/14:0 & 0.094 & 0.132 & 0.019 & 0.012 \\
\hline cis-9-18:1/18:0 & 1.92 & 2.08 & 2.81 & 1.74 \\
\hline cis-9, trans-11-CLA/trans-11-18:1 & 0.40 & 0.53 & 0.70 & 0.50 \\
\hline
\end{tabular}

Adapted from Shingfield et al. (2010)

${ }^{a}$ Response calculated as [((Treatment - Control $) /$ Control $\left.) \times 100\right]$

relative increases in milk cis-9-18:1 concentrations were lower than observed when comparable diets were fed to lactating cows (Roy et al. 2006; Chilliard et al. 2007). These interspecies differences could be related to a greater sensitivity of the SCD enzyme to the inhibitory effects of PUFA in the goat than the cow (Bernard et al. 2008) and/or to larger increases in the enrichment of trans-FA that may act as inhibitor of SCD in the goat compared to the cows receiving similar diets (such as trans-9, trans-11-CLA in goat milk in Bernard et al. (2009c) compared to bovine milk in Roy et al. (2006); Table 13.2; see section "In Vivo Studies with Specific Fatty Acid Infusion or Injection"). Moreover, the balance between (1) the level and nature of unsaturated FA taken up by the mammary gland and (2) the mammary synthesis of short-chain FA and desaturase activity, which play a role in the regulation of milk fat fluidity (Toral et al. 2013a), may intervene in explaining these interspecies differences. Indeed, it may be hypothesized that the goat which has higher 
concentrations of milk short-chain FA (Table 13.2) would require lower level of $\triangle-9$ desaturation for maintaining the milk fat melting point. However, in the absence of direct comparisons between bovine and small ruminant species with similar dietary conditions and stage of lactation, it is difficult to draw clear conclusions on species specificities of SCD regulation.

\section{Mechanisms of the Nutritional Regulation of Mammary SCD}

\section{In Vivo Studies with Specific Fatty Acid Infusion or Injection}

A key role for specific fatty acids on mammary lipogenesis and desaturation was showed from in vivo studies (Shingfield et al. 2010). In particular, studies with specific dietary conditions inducing a dramatic MFD (Bauman and Griinari 2003) underlined the role of specific trans-FA that act as potent inhibitors of mammary lipid synthesis and desaturation process. Indeed, as diet-induced MFD was associated with an increase in milk trans-10-18:1 content (Griinari et al. 1998; Piperova et al. 2000; Loor et al. 2005b) and trans-10, cis-12-CLA (Baumgard et al. 2000), these FA were proposed as candidates for inhibition of mammary lipogenesis (Bauman and Griinari 2001). Studies with post-ruminal infusion of trans-10, cis12-CLA clearly demonstrated the anti-lipogenic effect of this CLA isomer which was however not always accompanied by a reduction of milk desaturation ratios. Then, post-ruminal infusion studies in lactating cows have established that in amounts above $5 \mathrm{~g} /$ day, trans-10, cis-12-CLA typically decreased milk FA desaturation ratios consistent with a decrease in SCDI mRNA abundance (Table 13.3). In the bovine, in vivo studies indicated that injection or infusion of trans-10, cis-12CLA decreased mammary SCD1 gene transcription (Baumgard et al. 2002; Gervais et al. 2009), whereas no effect was observed on SCD5 (Gervais et al. 2009). In cows, the responses of mRNA abundances of the lipogenic genes involved in other pathways than desaturation (de novo FA synthesis, FA uptake, transport and esterification) to either diets that induce MFD (Table 13.1) or trans-10, cis-12-CLA infusion (Tables 13.3 and 13.4) showed a large decrease that occurred prior to a decrease in SCDI mRNA. It is likely that the responses of lipogenic genes and $S C D 1$ to these factors reflect a two-step phenomenon which could be related to differences in the response to the transcription factors involved in these regulations (see section "Knowledge on the Signalling Pathways Mediating Nutritional Regulation of SCD Gene Expression in Ruminants"). Otherwise, in the caprine, administration of trans-10, cis-12-CLA directly at the duodenum (Andrade and Schmidely 2006) or fed as calcium salts (Shingfield et al. 2009) was reported to lower milk FA desaturation ratios in the absence (Andrade and Schmidely 2006) or with a small decrease (Shingfield et al. 2009; Table 13.3) in milk fat secretion. Similarly, in the ovine, distribution of trans-10, cis-12-CLA as encapsulated lipids was reported to lower milk fat secretion and FA desaturation ratios (Lock et al. 2006). 


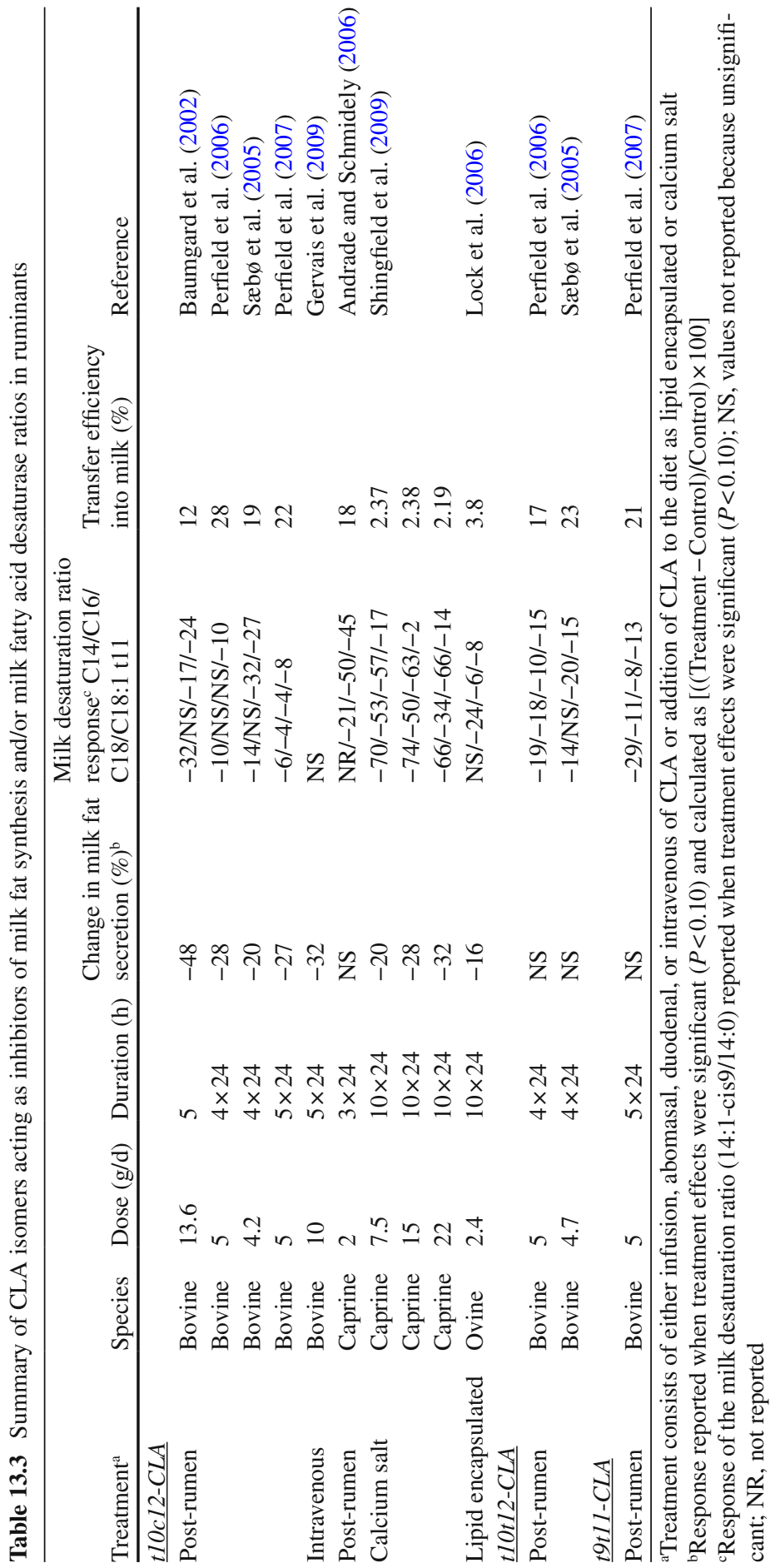




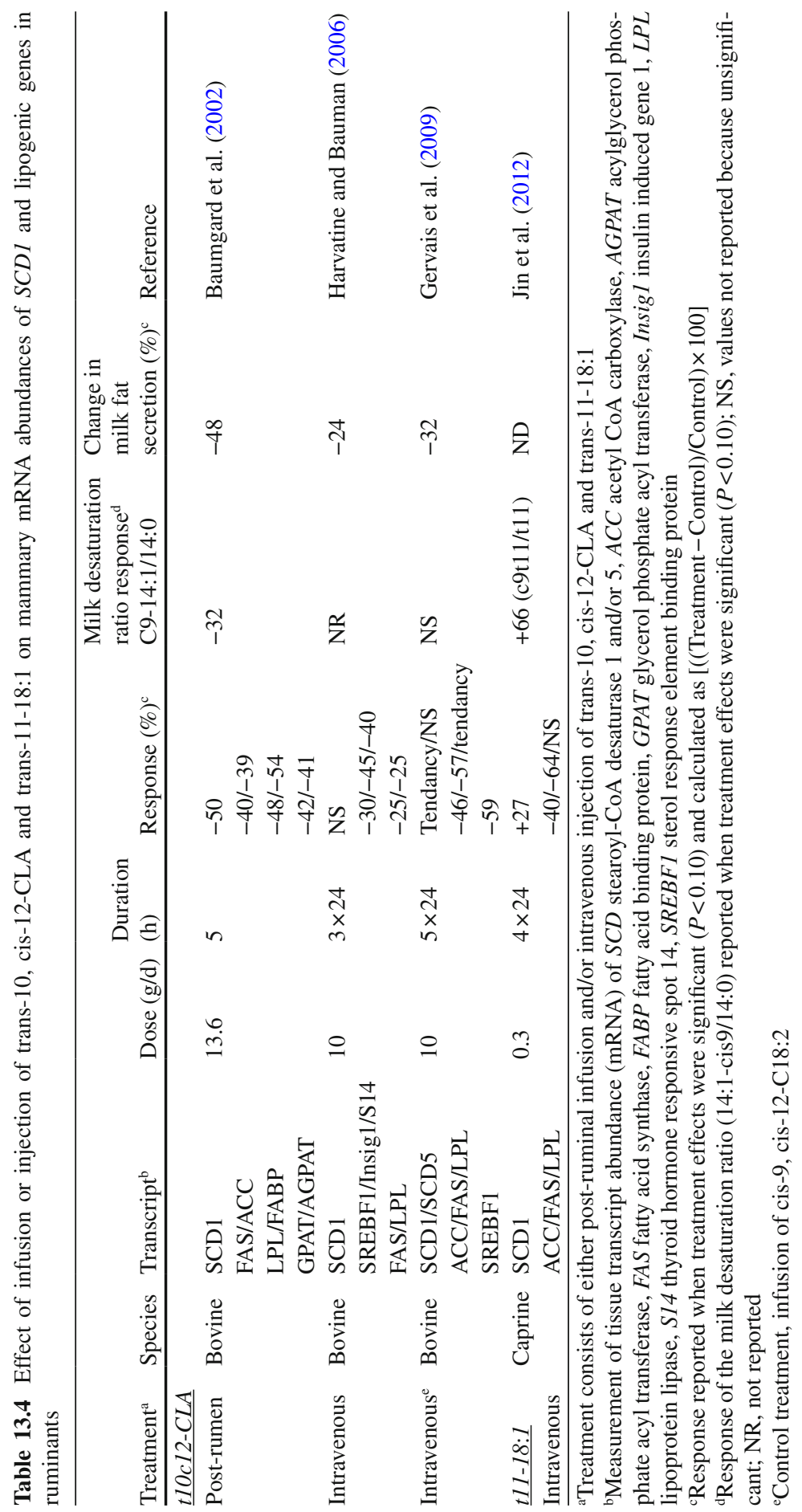


From data in ruminant species (Tables 13.1, 13.3, and 13.4), it may be hypothesized that whereas mammary lipogenic genes expression (at the level of the mRNA and protein) in caprine is less sensitive to the anti-lipogenic effect of the trans-10, cis12-CLA than in cows, for SCD protein the figure could be different with a higher sensitivity in goats. Indeed, indirect comparison from studies in goats (Bernard et al. 2009c) and cows (Roy et al. 2006) with similar dietary conditions (diets based on maize silage and supplemented with $5 \%$ sunflower oil) showed that the four milk FA desaturation ratios decreased in goats, whereas these ratios increased in cows (Table 13.2).

Moreover, post-ruminal infusion studies in cows have shown that in addition to trans-10, cis-12-CLA, trans-10, trans-12- (Sæbø et al. 2005) and trans-9, trans-11-CLA (Perfield et al. 2007) reduced milk FA desaturation ratios (Table 13.3), and therefore, these two latter biohydrogenation intermediates could be specific inhibitors of SCD activity since they were not associated with MFD. In particular, the high response of milk trans-9, trans-11-CLA in goats receiving sunflower oil could play a direct role in the typical decrease of milk FA desaturation ratios in this animal species (Table 13.2). Otherwise, abomasal infusions in cows and ewes (Griinari et al. 2000; Corl et al. 2001; Kay et al. 2004; Bichi et al. 2012) of sterculic oil, known as a strong inhibitor of SCD, and administration of Co-EDTA in the rumen or per os (Shingfield et al. 2006, 2008a; Taugbøl et al. 2008, 2010; Karlengen et al. 2012) decreased the milk FA desaturation ratios without alteration of mammary SCD1 mRNA abundance (Karlengen et al. 2012) and without decreasing milk fat secretion. It was hypothesized (Shingfield et al. 2008a) that Cobalt interferes with the transfer of electrons from cytochrome $b 5$ to the di-iron protein center of the terminal desaturase protein, thus altering the oxidation-reduction reactions of the conversion of the acyl-CoA substrates. In bovine the concomitant effects of trans10, cis-12-CLA on mammary $S C D 1$ mRNA abundance and milk FA desaturation ratios (Table 13.4) suggest an effect at the level of $S C D 1$ transcription for this CLA isomer. Otherwise, the mechanisms by which trans-10, trans-12 CLA and trans-9, trans-11 CLA decreased milk FA desaturation ratios are not clear and could involve an inhibition of $S C D 1$ gene transcription or activity.

\section{In Vitro Studies on the Effect of Fatty Acids on Mammary SCD}

Few in vitro systems have been developed to investigate the role of specific FA on the regulation of mammary lipogenesis (Table 13.5), including: (1) dispersed bovine mammary epithelial cells (bMECs) (Hansen et al. 1986; Hansen and Knudsen 1987) or primary bMECs (Matitashvili and Bauman 2000); (2) bMEC lines (MAC-T (Jayan and Herbein 2000; Peterson et al. 2004; Kadegowda et al. 2009; Ma and Corl 2012), BME-UV (McFadden et al. 2008)) or the cloned bMECs (Liu et al. 2006; Yonezawa et al. 2008); and (3) mammary slices (Matitashvili et al. 2001; Bernard et al. 2012). Although they are a simplification of physiological conditions, these 


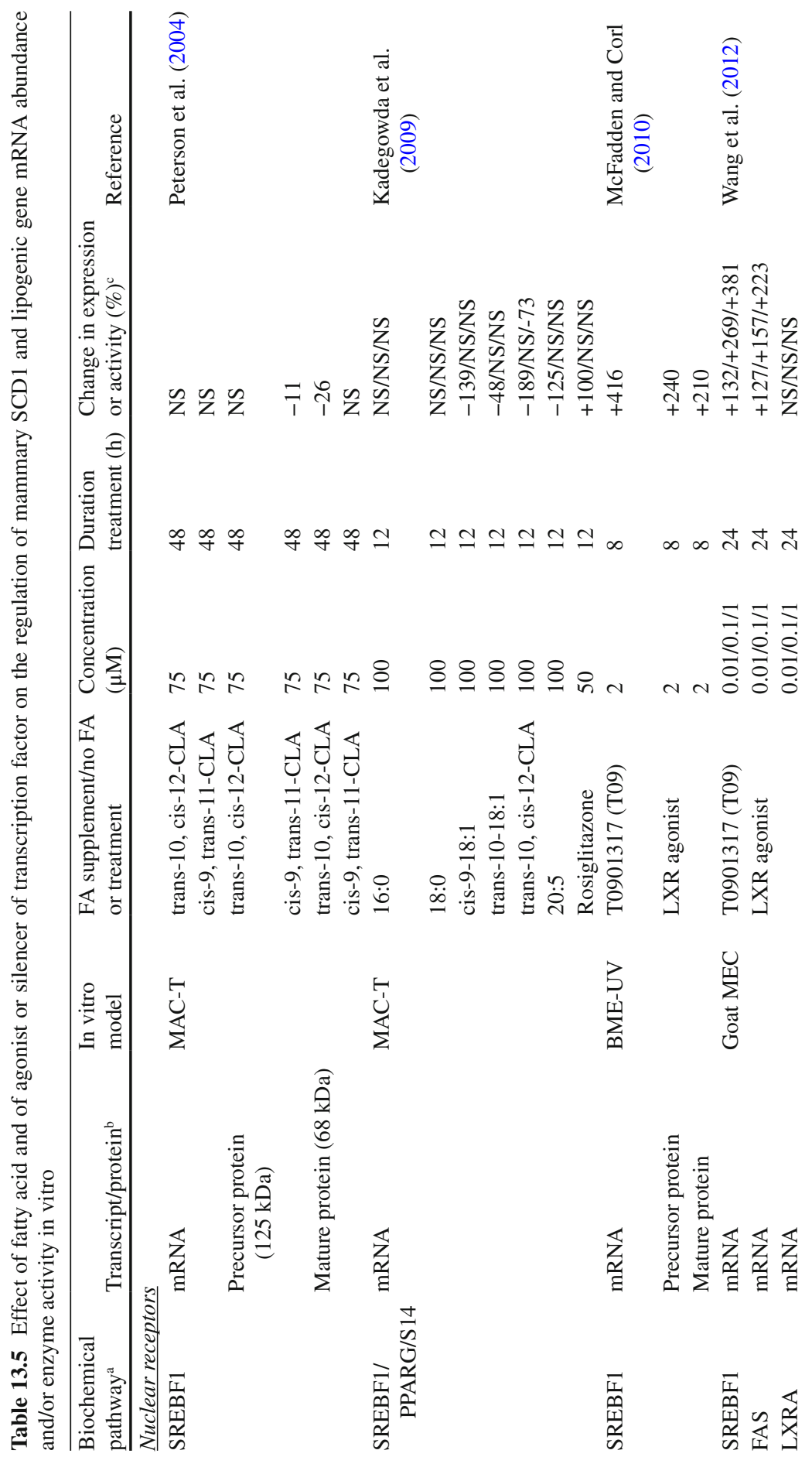


13 Expression and Nutritional Regulation of Stearoyl-CoA Desaturase Genes...

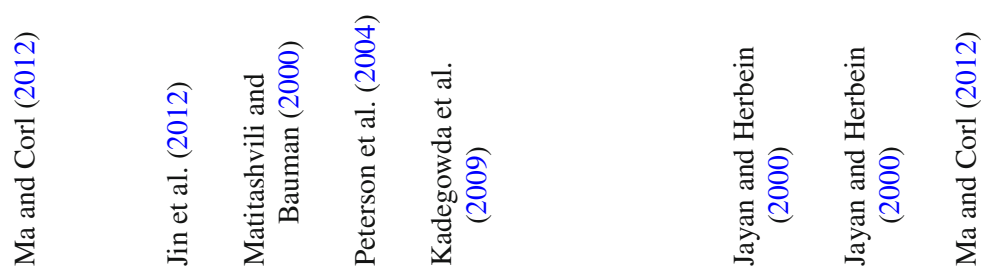

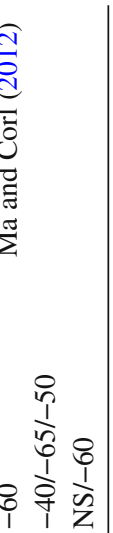

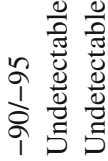

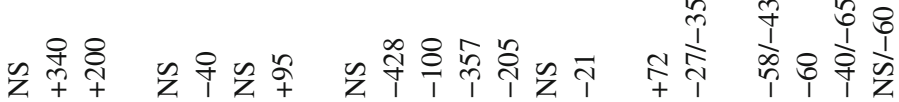

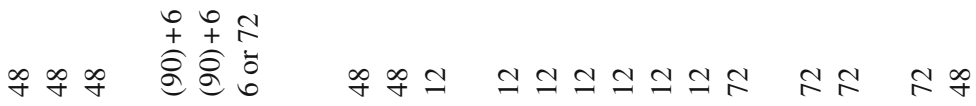

あேあ

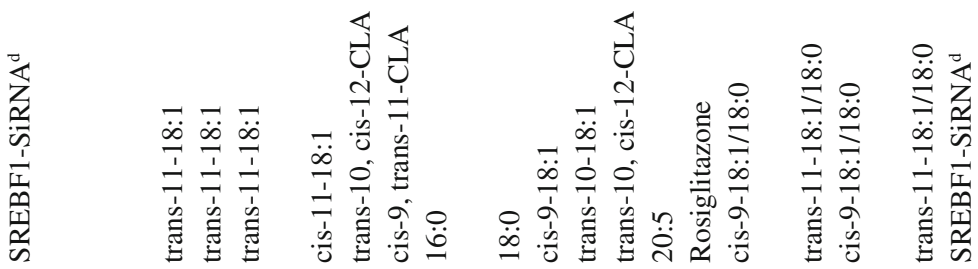

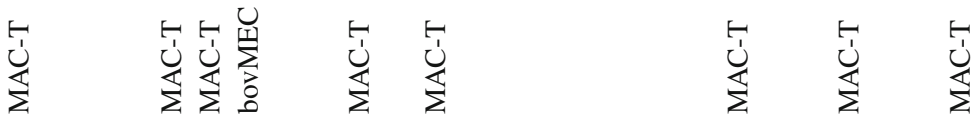

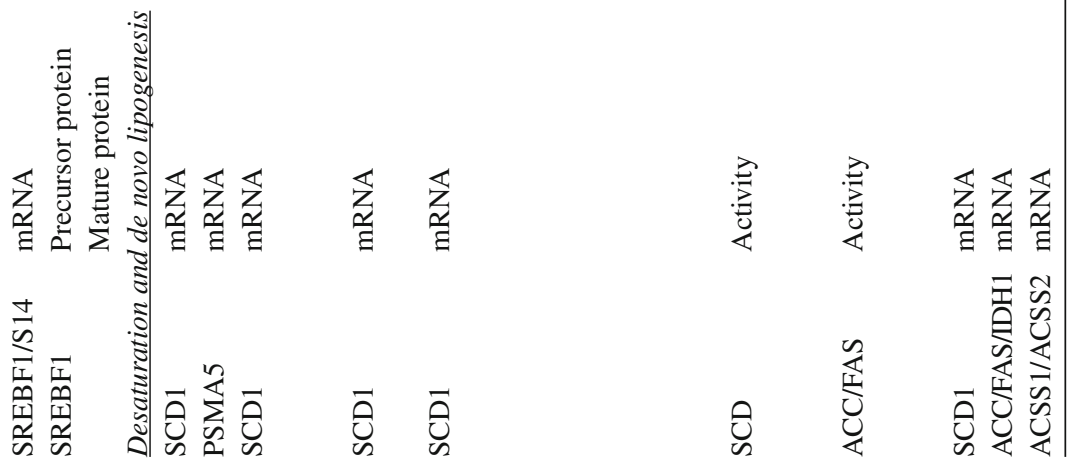




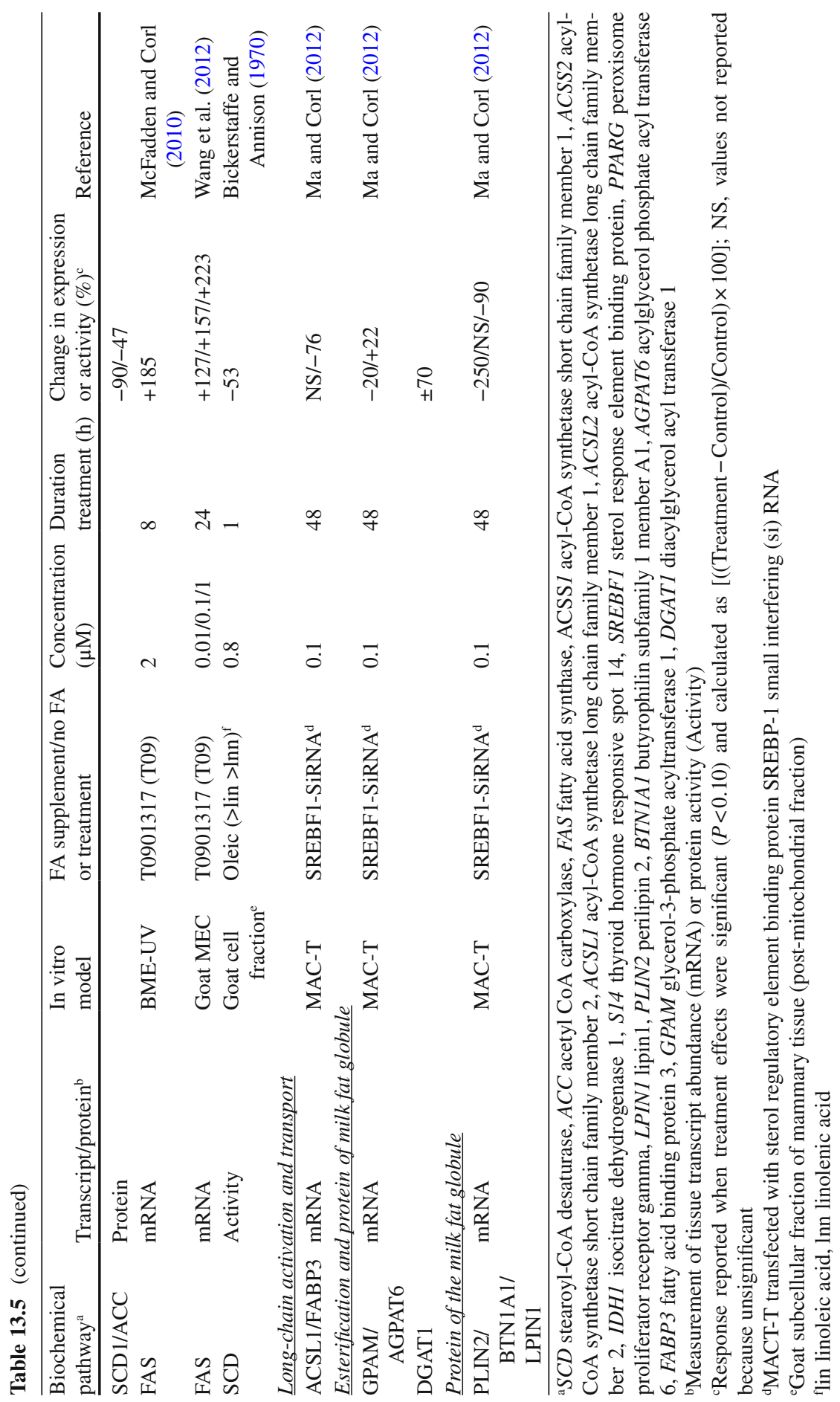


in vitro systems offer an advantage over in vivo nutritional studies because the effects of specific FA in small amount can be evaluated under controlled conditions. Then, several years ago looking at the effects of specific FA on bovine mammary cell line (MAC-T cells), Jayan and Herbein (2000) showed that, compared to stearic acid, oleic acid decreased SCD activity. Similarly, still using MAC-T cell, Kadegowda et al. (2009) demonstrated that oleic acid, among other long-chain FA including 20:5n-3, was the most potent inhibitor of $S C D$ gene expression, which is suggestive of a feedback-inhibition mechanism. Furthermore, earlier studies (Bickerstaffe and Annison 1970) observed negative effects of oleic, linoleic, and linolenic acids on goat mammary SCD activity measured on the subcellular fraction of goat mammary gland, which have been partly confirmed by in vivo studies on goat (Bernard et al. 2005b, 2009b). Regarding the effect of trans-FA, only two trans18:1 isomers have been tested in vitro (Table 13.5). Incubation of trans-11-18:1 with bovine MEC increased SCDI mRNA abundance (Matitashvili and Bauman 2000) and SCD activity in bovine MAC-T cell line (Jayan and Herbein 2000), whereas trans-10-18:1 reduced SCD1 mRNA abundance in bovine MAC-T cell line (Kadegowda et al. 2009). Similarly, in goats, intravenous bolus injection of trans11-18:1 increased both the expression of $S C D$ in mammary tissue (Jin et al. 2012) and milk cis-9, trans-11-CLA, suggesting an upregulation of the expression at the protein level. Otherwise, trans-10, cis-12-CLA (and to a lesser extent cis-9, trans11-CLA) caused a significant reduction in $S C D$ transcriptional activity (Keating et al. 2006) in bovine MAC-T cells, due to the $S C D$ transcriptional enhancer element region (STE; see section "Characterization of SCD Genes"). The same study also showed that bovine $S C D$ promoter was upregulated by insulin and downregulated by oleic acid, whereas linoleic, linolenic, stearic, and vaccenic acids had no effect. Elsewhere, using bovine and caprine mammary slices, Bernard et al. (2012) did not evidenced significant effect of trans-10, cis-12-CLA on SCD1 mRNA abundance after $20 \mathrm{~h}$ incubation time. Conversely, in bovine MAC-T cell, Kadegowda et al. (2009) demonstrated that trans-10, cis-12-CLA reduced expression of SCD1 together with SREBF1. These two latter studies outline differences of response of different in vitro models for studying lipogenic genes expression.

So far, the developed in vitro systems present several limitations: MECs and cultured mammary slices have a limited lifetime, modified cell lines often have abnormal characteristics and low secretory activity. Nevertheless, use of these approaches has allowed to decipher, at least in part, the underlying mechanisms responsible for the inhibitory effects of trans-10, cis-12-CLA on lipogenesis and lipogenic gene expression in primary culture of bMEC (Matitashvili and Bauman 2000), MEC lines (Peterson et al. 2004; McFadden et al. 2008; Kadegowda et al. 2009), and mammary explants (Matitashvili et al. 2001) (see section "Knowledge on the Signalling Pathways Mediating Nutritional Regulation of SCD Gene Expression in Ruminants"). Further research is necessary in ruminants to identify the major regulators of FA desaturation which is hampered by the lack of pure trans18:1 and 18:2 isomers and by the difficulty to obtain an in vitro functional model for lipid synthesis and secretion (Barber et al. 1997; Bernard et al. 2012). 


\section{Knowledge on the Signalling Pathways Mediating Nutritional Regulation of SCD Gene Expression in Ruminants}

Whereas the signalling pathways involved in the regulation of $S C D$ gene expression by dietary factors (e.g., the inhibitory effect of PUFA) have been comprehensively described in rodent tissues (Nakamura and Nara 2004; Ntambi et al. 2004), still little is known about these mechanisms in ruminants. Among the class of transcription factors known as major regulators of lipid synthesis are the sterol response element binding protein (SREBP) family (Eberlé et al. 2004) and peroxisome proliferators-activated receptors (PPARs) (Clarke 2001).

Because different SREBP isoforms have different roles in regulating lipid synthesis, these isoforms have been studied extensively in different species (Brown and Goldstein 1997).

SREBP family is composed of three members: two isoforms of SREBP-1 (a and c) and SREBP-2. Both SREBP-1a and SREBP-1c, which can be differentially expressed in various tissues, are produced from a single gene (SREBF-1, located on bovine chromosome 17) presenting alternative splicing. SREBFIc and SREBFIa use different first exons and both regulate FA synthesis. SREBP-2 is transcribed from a separate gene (SREBF2, located on bovine chromosome 5) and regulates the cholesterol biosynthetic pathway (Horton 2002).

Multiple proteins are involved in the SREBP pathway because (1) SREBP are translated as precursor proteins which need maturation steps to become mature that involve several proteins (such as SCAP, INSIG1, 2, S1P, S2P) and (2) the SREBP mature proteins recruit other proteins acting as co-activators to activate the transcription of lipogenic genes to whom belong $L P L, A C A C A, F A S N$, and $S C D 1$ genes.

Regarding PPARs, three different isoforms of PPAR (PPAR $\alpha$, PPAR $\beta / \delta$, and PPAR $\gamma$ ), have been identified and are encoded by three different genes; they exhibit significant differences in tissue distribution and ligands but all function by dimerizing with RXR and binding to the PPAR response element (PPRE) DNA sequence (Sampath and Ntambi 2005).

In lactating cows, in vivo studies have shown the involvement of SREBP-1 and/ or PPAR during diet-induced changes in mammary lipogenic gene expression (Angulo et al. 2012; Bionaz and Loor 2008) or in response to 3-5 d intravenous infusions of trans-10, cis-12-CLA (Harvatine and Bauman 2006; Gervais et al. 2009) with the implication that these transcription factors are central elements in the overall regulation of milk fat synthesis.

However, little is known in the ruminant mammary gland on the signalling pathways involved in $S C D$ gene expression. Among six in vivo studies (either nutritional or infusion studies) in cows with MFD that measured the mammary mRNA abundances of both lipogenic genes and $S C D 1$, only two reported a simultaneous decrease in mRNA abundance of lipogenic genes and SCD1 (Baumgard et al. 2002; Angulo et al. 2012). Conversely, in the others, either nutritional studies (Ahnadi et al. 2002; Harvatine and Bauman 2006; Peterson et al. 2003) or with intravenous 


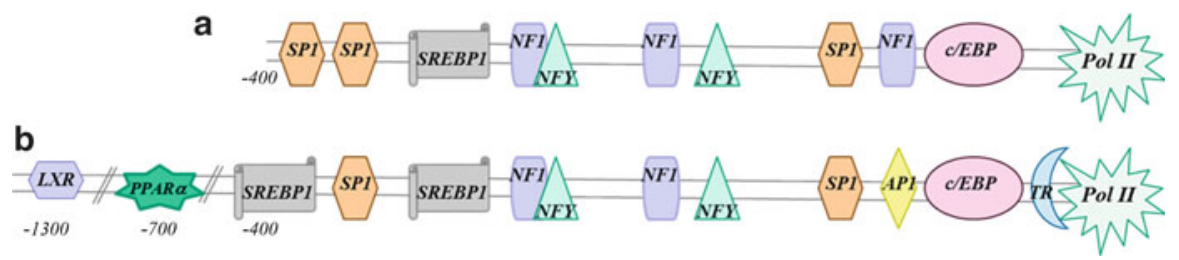

Fig. 13.5 Diagram of the SCD1 gene promoter. The diagram shows the different transcription factors involved in the regulation of SCD1 gene transcription. (a) Represents the binding sites of transcription factors deduced by sequence homology between bovine sequence (AY241932) and pig (AY487830) and human (AF 320307). (b) Represents elements characterized in human, mouse, and chicken promoters from Mauvoisin and Mounier (2011)

infusion of trans-10, cis-12-CLA (Gervais et al. 2009), a coordinate decrease in the abundance of lipogenic genes was observed with only a tendency to decrease for $S C D 1$ mRNA suggesting that the transcription of this gene varies less or less rapidly in response to the diet. Probably the other lipogenesis-related transcription factors (e.g., PPARs, SP1, NFY, CEBPs; Fig. 13.5) expressed in the ruminant mammary gland (Bionaz and Loor 2008; Toral et al. 2013b) are involved in the mediation of diet-induced effects on mammary $S C D 1$ gene expression that may counteract for the effect of SREBF1.

Otherwise, in an in vitro study using bovine MAC-T cell line, addition of trans10, cis-12-CLA and 20:5n-3 decreased both SREBF1 and SCD1 mRNA abundances with variable effects on the other lipogenic genes and without changing PPARG mRNA (Kadegowda et al. 2009). Recently, it was reported that the bovine SREBF1 gene contained in its promoter responsive elements for both SREBFl (SRE) that could allow for a positive feedback regulation by SREBP-1 itself and for liver X receptor (LXR-RE; Lengi and Corl 2010). Therefore, the SREBP-1 responsiveness to LXR activation was demonstrated in BME-UV cell line (McFadden and Corl 2010) using T0901317 (T09), an LXR agonist that resulted in the upregulation of transcription, translation, and proteolytic cleavage of SREBP-1. Because both SRE and LXR-RE have been characterized in SCD1 gene promoter in human, mouse, or chicken (Mauvoisin and Mounier 2011) and are conserved between species, probably they may also be present in bovine $S C D 1$ gene promoter. Using bovine MAC-T cell line, Peterson et al. (2004) have demonstrated that the inhibitory effect of trans10, cis-12-CLA acts through inhibition of the proteolytic activation of SREBP-1, resulting in a reduction in the transcriptional activation of lipogenic genes ( $A C A C A$ and $F A S N$ ) and $S C D 1$, without increasing the SREBF1 expression. The role of SREBP-1 in regulating milk fat synthesis had not been directly evaluated in ruminants until a recent study in MAC-T cells (Ma and Corl 2012) using RNA interference to knock down $S R E B F 1$ (the $S R E B F 1$-specific siRNA targeted a region of the transcript identical between SREBFIa and SREBFIc and did not distinguish the two isoforms 1a and 1c) to investigate the specific role of SREBP-1 in affecting the expression of genes encoding key enzymes of milk fat synthesis including SCDI. In this study, 
FABP3 and SCD1 mRNAs were both decreased when SREBP-1 mRNA decreased (and SREBP protein was undetectable), indicating that transport and desaturation of long-chain FA could be regulated transcriptionally by SREBP-1.

Altogether these data underlined the necessity to better characterize the molecular mechanisms involved in the dietary regulation of $S C D$ gene expression in ruminant species, and in particular to precise the role of SREBP-1 and PPARs. The observed differences in the response of $S C D$ and other lipogenic genes expression to decreased SREBF1 mRNA abundance (Table 13.1) may suggest a lower threshold response for $S C D$ to SREBP-1 level compared to other lipogenic genes which would be in line with the hypothesis of a two-step mechanisms of regulation for these genes, with the implication of other transcription factors in these regulations.

\section{Conclusions}

A balance between the endogenously synthesized short-chain FA, the exogenous unsaturated long-chain FA, and the SCD desaturation products must be maintained within the mammary gland in order to preserve the fluidity of milk fat, which emphasizes the importance of knowledge on SCD regulation. Over the last years, the development of studies in ruminants on the nutritional regulation of a few "candidate" genes involved in mammary lipogenesis including $\triangle 9$-desaturation $(S C D)$ has shown that $S C D$ gene regulation differ from other lipogenic genes. Indeed, in cows with dietary conditions that induce a dramatic MFD, a decrease in the mRNA abundance of mammary lipogenic genes was observed which was not always observed for $S C D$. It was hypothesized that the responses of lipogenic genes and SCDI to dietary factors that induce MFD in cows occur as a two-step phenomenon, with a first downregulation of lipogenic genes followed by $S C D 1$, which could be related to the observed differences in the response to $S R E B F 1$ or to other transcription factors involved in these regulations. In addition, these studies showed that the response of mammary $S C D$ mRNA or activity to nutritional factors do not always match with the responses of milk FA $\Delta-9$ desaturation ratios. In goats, $S C D$ is regulated at a transcriptional and/or post-transcriptional level, depending on the lipid supplements. Conversely, in cows, data converged to demonstrate that $S C D$ mRNA varied little in response to diet except for a decrease when "protected" fish oil or combination of PUFA and DHA-rich algae was fed. Indirect comparison of data from bovine and caprine suggested that SCD in caprine could be more sensitive to the effect of dietary PUFA or their ruminal biohydrogenation intermediates than in cows and that trans-9, trans-11-CLA could play a specific role in the regulation of mammary $\Delta-9$ desaturation in goats receiving PUFA-rich diets. Future experiments examining changes in mammary $S C D$ and other lipogenic genes expression in the different ruminant species in response to dietary treatments as well as ruminant $S C D 1$ and $S C D 5$ promoter sequencing would provide a more comprehensive insight into the regulation of these genes and their impact in the synthesis of milk fat. 


\section{References}

Ahnadi CE, Beswick N, Delbecchi L, Kennelly JJ, Lacasse P (2002) Addition of fish oil to diets for dairy cows. II. Effects on milk fat and gene expression of mammary lipogenic enzymes. J Dairy Res 69(4):521-531

Alim MA, Fan YP, Wu XP, Xie Y, Zhang Y, Zhang SL, Sun DX, Zhang Y, Zhang Q, Liu L et al (2012) Genetic effects of stearoyl-coenzyme A desaturase (SCD) polymorphism on milk production traits in the Chinese dairy population. Mol Biol Rep 39(9):8733-8740

Andrade PVD, Schmidely P (2006) Effect of duodenal infusion of trans10, cis12-CLA on milk performance and milk fatty acid profile in dairy goats fed high or low concentrate diet in combination with rolled canola seed. Reprod Nutr Dev 46(1):31-48

Angulo J, Mahecha L, Nuernberg K, Nuernberg G, Dannenberger D, Olivera M, Boutinaud M, Leroux C, Albrecht E, Bernard L (2012) Effects of polyunsaturated fatty acids from plant oils and algae on milk fat yield and composition are associated with mammary lipogenic and SREBF1 gene expression. Animal 6:1-12

Annison EF, Bickerstaffe R, Linzell JL (1974) Glucose and fatty acid metabolism in cows producing milk of low fat content. J Agric Sci 82:87-95

Barber MC, Clegg RA, Travers MT, Vernon RG (1997) Lipid metabolism in the lactating mammary gland. Biochim Biophys Acta 1347(2-3):101-126

Bauman DE, Corl BA, Baumgard LH, Griinari JM (2001) Conjugated linoleic acid (CLA) and the dairy cow. In: Recent advances in animal nutrition, Garnsworthy PC, Wiseman J (eds), Nottingham university press, Nottingham, p 221-250

Bauman DE, Griinari JM (2001) Regulation and nutritional manipulation of milk fat: low-fat milk syndrome. Livest Prod Sci 70(1-2):15-29

Bauman DE, Griinari JM (2003) Nutritional regulation of milk fat synthesis. Annu Rev Nutr 23:203-227

Baumgard LH, Corl BA, Dwyer DA, Sæbø A, Bauman DE (2000) Identification of the conjugated linoleic acid isomer that inhibits milk fat synthesis. Am J Physiol Regul Integr Comp Physiol 278(1):R179-R184

Baumgard LH, Matitashvili E, Corl BA, Dwyer DA, Bauman DE (2002) Trans-10, cis-12 conjugated linoleic acid decreases lipogenic rates and expression of genes involved in milk lipid synthesis in dairy cows. J Dairy Sci 85(9):2155-2163

Bernard L, Bonnet M, Leroux C, Shingfield KJ, Chilliard Y (2009a) Effect of sunflower-seed oil and linseed oil on tissue lipid metabolism, gene expression, and milk fatty acid secretion in Alpine goats fed maize silage-based diets. J Dairy Sci 92(12):6083-6094

Bernard L, Leroux C, Bonnet M, Rouel J, Martin P, Chilliard Y (2005a) Expression and nutritional regulation of lipogenic genes in mammary gland and adipose tissues of lactating goats. J Dairy Res 72(2):250-255

Bernard L, Leroux C, Chilliard Y (2008) Expression and nutritional regulation of lipogenic genes in the ruminant lactating mammary gland. Adv Exp Med Biol 606:67-108

Bernard L, Leroux C, Faulconnier Y, Durand D, Shingfield KJ, Chilliard Y (2009b) Effect of sunflower-seed oil or linseed oil on milk fatty acid secretion and lipogenic gene expression in goats fed hay-based diets. J Dairy Res 76(241-248)

Bernard L, Leroux C, Hayes H, Gautier M, Chilliard Y, Martin P (2001) Characterization of the caprine stearoyl-CoA desaturase gene and its mRNA showing an unusually long 3'-UTR sequence arising from a single exon. Gene 281(1-2):53-61

Bernard L, Montazer Torbati MB, Graulet B, Leroux C, Chilliard Y (2012) Long-chain fatty acids differentially alter lipogenesis in bovine and caprine mammary slices. J Dairy Res 80(89-95)

Bernard L, Mouriot J, Rouel J, Glasser F, Capitan P, Pujos-Guillot E, Chardigny JM, Chilliard Y (2010) Effects of fish oil and starch added to a diet containing sunflower-seed oil on dairy goat performance, milk fatty acid composition and in vivo delta 9-desaturation of [C-13] vaccenic acid. Br J Nutr 104(3):346-354 
Bernard L, Rouel J, Leroux C, Ferlay A, Faulconnier Y, Legrand P, Chilliard Y (2005b) Mammary lipid metabolism and milk fatty acid secretion in alpine goats fed vegetable lipids. J Dairy Sci 88(4):1478-1489

Bernard L, Shingfield KJ, Rouel J, Ferlay A, Chilliard Y (2009c) Effect of plant oils in the diet on performance and milk fatty acid composition in goats fed diets based on grass hay or maize silage. Br J Nutr 101(2):213-224

Bichi E, Toral PG, Hervás G, Frutos P, Gómez-Cortés P, Juárez M, de la Fuente MA (2012) Inhibition of $\Delta 9$-desaturase activity with sterculic acid: effect on the endogenous synthesis of cis-9 18:1 and cis-9, trans-11 18:2 in dairy sheep. J Dairy Sci 95(9):5242-5252

Bickerstaffe R, Annison EF (1970) The desaturase activity of goat and sow mammary tissue. Comp Biochem Physiol 35:653-665

Bionaz M, Loor JJ (2008) Gene networks driving bovine milk fat synthesis during the lactation cycle. BMC Genomics 9:366

Brown MS, Goldstein JL (1997) The SREBP pathway: regulation of cholesterol metabolism by proteolysis of a membrane-bound transcription factor. Cell 89(3):331-340

Carta A, Casu S, Usai MG, Addis M, Fiori M, Fraghi A, Miari S, Mura L, Piredda G, Schibler L et al (2008) Investigating the genetic component of fatty acid content in sheep milk. Small Ruminant Res 79(1):22-28

Chilliard Y, Ferlay A, Mansbridge RM, Doreau M (2000) Ruminant milk fat plasticity: nutritional control of saturated, polyunsaturated, trans and conjugated fatty acids. Ann Zootechnol 49(3):181-205

Chilliard Y, Glasser F, Ferlay A, Bernard L, Rouel J, Doreau M (2007) Diet, rumen biohydrogenation and nutritional quality of cow and goat milk fat. Eur J Lipid Sci Technol 109(8):828-855

Chilliard Y, Rouel J, Leroux C (2006) Goat's alpha-s1 casein genotype influences its milk fatty acid composition and delta-9 desaturation ratios. Anim Feed Sci Technol 131(3-4):474-487

Christie WW (1981) The composition, structure and function of lipids in the tissues of ruminant animals. In: Christie WW (ed) Lipid metabolism in ruminant animals. Pergamon press, Oxford, pp 95-192

Chung M, Ha S, Jeong S, Bok J, Cho K, Baik M, Choi Y (2000) Cloning and characterization of bovine stearoyl CoA desaturasel cDNA from adipose tissues. Biosci Biotechnol Biochem 64(7):1526-1530

Clarke SD (2001) Polyunsaturated fatty acid regulation of gene transcription: a molecular mechanism to improve the metabolic syndrome. J Nutr 131(4):1129-1132

Conte G, Mele M, Chessa S, Castiglioni B, Serra A, Pagnacco G, Secchiari P (2010) Diacylglycerol acyltransferase 1 , stearoyl-CoA desaturase 1 , and sterol regulatory element binding protein 1 gene polymorphisms and milk fatty acid composition in Italian Brown cattle. J Dairy Sci 93(2):753-763

Corl BA, Baumgard LH, Dwyer DA, Griinari JM, Phillips BS, Bauman DE (2001) The role of delta(9)-desaturase in the production of cis-9, trans-11 CLA. J Nutr Biochem 12(11):622-630

Corl BA, Baumgard LH, Griinari JM, Delmonte P, Morehouse KM, Yuraweczc MP, Bauman DE (2002) Trans-7, cis-9 CLA is synthesized endogenously by delta(9)-desaturase in dairy cows. Lipids 37(7):681-688

Delbecchi L, Ahnadi CE, Kennelly JJ, Lacasse P (2001) Milk fatty acid composition and mammary lipid metabolism in Holstein cows fed protected or unprotected canola seeds. J Dairy Sci 84(6): 1375-1381

Dewhurst RJ, Shingfield KJ, Lee MRF, Scollan ND (2006) Increasing the concentrations of beneficial polyunsaturated fatty acids in milk produced by dairy cows in high-forage systems. Anim Feed Sci Technol 131(3-4):168-206

Eberlé D, Hegarty B, Bossard P, Ferre P, Foufelle F (2004) SREBP transcription factors: master regulators of lipid homeostasis. Biochimie 86(11):839-848

Enjalbert F, Nicot MC, Bayourthe C, Moncoulon R (1998) Duodenal infusions of palmitic, stearic or oleic acids differently affect mammary gland metabolism of fatty acids in lactating dairy cows. J Nutr 128(9):1525-1532 
Gama MAS, Garnsworthy PC, Griinari JM, Leme PR, Rodrigues PHM, Souza LWO, Lanna DPD (2008) Diet-induced milk fat depression: association with changes in milk fatty acid composition and fluidity of milk fat. Livest Sci 115(2-3):319-331

Garcia-Fernandez M, Gutierrez-Gill B, Garcia-Gamez E, Arranz JJ (2009) Genetic variability of the stearoyl-CoA desaturase gene in sheep. Mol Cell Probes 23(2):107-111

Garcia-Fernandez M, Gutierrez-Gil B, Garcia-Gamez E, Sanchez JP, Arranz JJ (2010) Detection of quantitative trait loci affecting the milk fatty acid profile on sheep chromosome 22: role of the stearoyl-CoA desaturase gene in Spanish Churra sheep. J Dairy Sci 93(1):348-357

Gervais R, McFadden JW, Lengi AJ, Corl BA, Chouinard PY (2009) Effects of intravenous infusion of trans-10, cis-12 18: 2 on mammary lipid metabolism in lactating dairy cows. J Dairy Sci 92(10):5167-5177

Glasser F, Ferlay A, Doreau M, Schmidely P, Sauvant D, Chilliard Y (2008) Long-chain fatty acid metabolism in dairy cows: a meta-analysis of milk fatty acid yield in relation to duodenal flows and de novo synthesis. J Dairy Sci 91(7):2771-2785

Griinari JM, Corl BA, Lacy SH, Chouinard PY, Nurmela KVV, Bauman DE (2000) Conjugated linoleic acid is synthesized endogenously in lactating dairy cows by delta(9)-desaturase. J Nutr 130(9):2285-2291

Griinari JM, Dwyer DA, McGuire MA, Bauman DE, Palmquist DL, Nurmela KV (1998) Transoctadecenoic acids and milk fat depression in lactating dairy cows. J Dairy Sci 81(5):1251-1261

Hansen HO, Knudsen J (1987) Effect of exogenous long-chain fatty acids on lipid biosynthesis in dispersed ruminant mammary gland epithelial cells: esterification of long-chain exogenous fatty acids. J Dairy Sci 70(7):1344-1349

Hansen HO, Tornehave D, Knudsen J (1986) Synthesis of milk specific fatty acids and proteins by dispersed goat mammary-gland epithelial cells. Biochem J 238(1):167-172

Harvatine KJ, Bauman DE (2006) SREBP1 and thyroid hormone responsive spot 14 (S14) are involved in the regulation of bovine mammary lipid synthesis during diet-induced milk fat depression and treatment with CLA. J Nutr 136(10):2468-2474

Horton JD (2002) Sterol regulatory element-binding proteins: transcriptional activators of lipid synthesis. Biochem Soc Trans 30:1091-1095

Invernizzi G, Thering BJ, McGuire MA, Savoini G, Loor JJ (2010) Sustained upregulation of stearoyl-CoA desaturase in bovine mammary tissue with contrasting changes in milk fat synthesis and lipogenic gene networks caused by lipid supplements. Funct Integr Genomics 10(4):561-575

Jacobs AAA, van Baal J, Smits MA, Taweel HZH, Hendriks WH, van Vuuren AM, Dijkstra J (2011) Effects of feeding rapeseed oil, soybean oil, or linseed oil on stearoyl-CoA desaturase expression in the mammary gland of dairy cows. J Dairy Sci 94(2):874-887

Jayan GC, Herbein JH (2000) "Healthier" dairy fat using trans-vaccenic acid. Nutr Food Sci 30(6):304-309

Jensen RG (2002) The composition of bovine milk lipids: January 1995 to December 2000. J Dairy Sci 85(2):295-350

Jin YC, Li ZH, Hong ZS, Xu CX, Han JA, Choi SH, Yin JL, Zhang QK, Lee KB, Kang SK et al (2012) Conjugated linoleic acid synthesis-related protein proteasome subunit $\alpha 5$ (PSMA5) is increased by vaccenic acid treatment in goat mammary tissue. J Dairy Sci 95(8):4286-4297

Kadegowda AKG, Bionaz M, Piperova LS, Erdman RA, Loor JJ (2009) Peroxisome proliferatoractivated receptor-gamma activation and long-chain fatty acids alter lipogenic gene networks in bovine mammary epithelial cells to various extents. J Dairy Sci 92(9):4276-4289

Kaestner KH, Ntambi JM, Kelly TJJ, Lane MD (1989) Differentiation-induced gene expression in 3T3-L1 preadipocytes. A second differentially expressed gene encoding stearoyl-CoA desaturase. J Biol Chem 264(25):14755-14761

Karlengen IJ, Harstad OM, Taugbol O, Berget I, Aastveit AH, Vage DI (2012) The effect of excess cobalt on milk fatty acid profiles and transcriptional regulation of SCD, FASN, DGAT1 and DGAT2 in the mammary gland of lactating dairy cows. J Anim Physiol Anim Nutr 96(6): 1065-1073 
Kay JK, Mackle TR, Auldist MJ, Thomson NA, Bauman DE (2004) Endogenous synthesis of cis-9, trans-11 conjugated linoleic acid in dairy cows fed fresh pasture. J Dairy Sci 87(2):369-378

Keating AF, Kennelly JJ, Zhao FQ (2006) Characterization and regulation of the bovine stearoyl-CoA desaturase gene promoter. Biochem Biophys Res Commun 344(1):233-240

Keating AF, Stanton C, Murphy JJ, Smith TJ, Ross RP, Cairns MT (2005) Isolation and characterization of the bovine stearoyl-CoA desaturase promoter and analysis of polymorphisms in the promoter region in dairy cows. Mamm Genome 16(3):184-193

Kgwatalala PM, Ibeagha-Awemu EM, Hayes JF, Zhao X (2007) Single nucleotide polymorphisms in the open reading frame of the stearoyl-CoA desaturase gene and resulting genetic variants in Canadian Holstein and Jersey cows. DNA Seq 18(5):357-362

Kgwatalala PM, Ibeagha-Awemu EM, Hayes JF, Zhao X (2009a) Stearoyl-CoA desaturase 1 3'UTR SNPs and their influence on milk fatty acid composition of Canadian Holstein cows. J Anim Breed Genet 126(5):394-403

Kgwatalala PM, Ibeagha-Awemu EM, Mustafa AF, Zhao X (2009b) Stearoyl-CoA desaturase 1 genotype and stage of lactation influences milk fatty acid composition of Canadian Holstein cows. Anim Genet 40(5):609-615

Kinsella JE (1970) Stearic acid metabolism by mammary cells. J Dairy Sci 53(12):1757-1765

Legrand P, Catheline D, Fichot MC, Lemarchal P (1997) Inhibiting delta9-desaturase activity impairs triacylglycerol secretion in cultured chicken hepatocytes. J Nutr 127(2):249-256

Lengi AJ, Corl BA (2007) Identification and characterization of a novel bovine stearoyl-CoA desaturase isoform with homology to human SCD5. Lipids 42(6):499-508

Lengi AJ, Corl BA (2008) Comparison of pig, sheep and chicken SCD5 homologs: evidence for an early gene duplication event. Comp Biochem Physiol B Biochem Mol Biol 150(4):440-446

Lengi AJ, Corl BA (2010) Short communication: identification of the bovine sterol regulatory element binding protein-1c promoter and its activation by liver $\mathrm{X}$ receptor1. J Dairy Sci 93(12):5831-5836

Lengi AJ, Corl BA (2012) Regulation of the bovine SCD5 promoter by EGR2 and SREBP1. Biochem Biophys Res Commun 421(2):375-379

Lerch S, Shingfield KJ, Ferlay A, Vanhatalo A, Chilliard Y (2012) Rapeseed or linseed in grassbased diets: effects on conjugated linoleic and conjugated linolenic acid isomers in milk fat from Holstein cows over 2 consecutive lactations. J Dairy Sci 95(12):7269-7287

Li XZ, Yan CG, Lee HG, Choi CW, Song MK (2012) Influence of dietary plant oils on mammary lipogenic enzymes and the conjugated linoleic acid content of plasma and milk fat of lactating goats. Anim Feed Sci Technol 174(1-2):26-35

Liu W, Degner SC, Romagnolo DF (2006) Trans-10, cis-12 conjugated linoleic acid inhibits prolactin-induced cytosolic NADP + -dependent isocitrate dehydrogenase expression in bovine mammary epithelial cells. J Nutr 136(11):2743-2747

Lock AL, Teles BM, Perfield JW, Bauman DE, Sinclair LA (2006) A conjugated linoleic acid supplement containing trans-10, cis-12 reduces milk fat synthesis in lactating sheep. J Dairy Sci 89(5):1525-1532

Loor JJ, Doreau M, Chardigny JM, Ollier A, Sébédio JL, Chilliard Y (2005a) Effects of ruminal or duodenal supply of fish oil on milk fat secretion and profiles of trans-fatty acids and conjugated linoleic acid isomers in dairy cows fed maize silage. Anim Feed Sci Technol 119(3-4):227-246

Loor JJ, Ferlay A, Ollier A, Chilliard Y (2005b) Relationship among trans and conjugated fatty acids and bovine milk fat yield due to dietary concentrate and linseed oil. J Dairy Sci 88(2):726-740

Ma L, Corl BA (2012) Transcriptional regulation of lipid synthesis in bovine mammary epithelial cells by sterol regulatory element binding protein-1. J Dairy Sci 95(7):3743-3755

Matitashvili E, Bauman DE (2000) Effect of different isomers of C18:1 and C18:2 fatty acids on lipogenesis in bovine mammary epithelial cells. J Anim Sci 78(Supplement 1):165

Matitashvili E, Baumgard LH, Bauman DE (2001) The effect of trans-10, cis-12 conjugated linoleic acid (CLA) infusion on milk fat synthesis and expression of lipogenic enzymes in the mammary gland of lactating cows. J Anim Sci 79(Suppl 1):310 
Mauvoisin D, Mounier C (2011) Hormonal and nutritional regulation of SCD1 gene expression. Biochimie 93(1):78-86

McDonald TM, Kinsella JE (1973) Stearyl-CoA desaturase of bovine mammary microsomes. Arch Biochem Biophys 156(1):223-231

McFadden JW, Corl BA (2010) Activation of liver X receptor (LXR) enhances de novo fatty acid synthesis in bovine mammary epithelial cells. J Dairy Sci 93(10):4651-4658

McFadden JW, Mullarky IK, Corl BA (2008) Inhibitory effect of unsaturated fatty acids on de novo fatty acid synthesis in bovine mammary epithelial cells. J Anim Sci 86(E-Suppl 2):566

Mele M, Conte G, Castiglioni B, Chessa S, Macciotta NPP, Serra A, Buccioni A, Pagnacco G, Secchiari P (2007) Stearoyl-Coenzyme A desaturase gene polymorphism and milk fatty acid composition in Italian Holsteins. J Dairy Sci 90(9):4458-4465

Mihara K (1990) Structure and regulation of rat liver microsomal stearoyl-CoA desaturase gene. J Biochem 108(6):1022-1029

Miyazaki M, Bruggink SM, Ntambi JM (2006) Identification of mouse palmitoyl-coenzyme A Delta 9-desaturase. J Lipid Res 47(4):700-704

Miyazaki M, Jacobson MJ, Man WC, Cohen P, Asilmaz E, Friedman JM, Ntambi JM (2003) Identification and characterization of murine SCD4, a novel heart-specific stearoyl-CoA desaturase isoform regulated by leptin and dietary factors. J Biol Chem 278(36):33904-33911

Moioli B, Contarini G, Avalli A, Catillo G, Orru L, De Matteis G, Masoero G, Napolitano F (2007) Short communication: effect of stearoyl-coenzyme A desaturase polymorphism on fatty acid composition of milk. J Dairy Sci 90(7):3553-3558

Mosley EE, McGuire MA (2007) Methodology for the in vivo measurement of the delta(9)-desaturation of myristic, palmitic, and stearic acids in lactating dairy cattle. Lipids 42:939-945

Mosley EE, Shafii B, Moate PJ, McGuire MA (2006) Cis-9, trans-11 conjugated linoleic acid is synthesized directly from vaccenic acid in lactating dairy cattle. J Nutr 136(3):570-575

Murrieta CM, Hess BW, Scholljegerdes EJ, Engle TE, Hossner KL, Moss GE, Rule DC (2006) Evaluation of milk somatic cells as a source of mRNA for study of lipogenesis in the mammary gland of lactating beef cows supplemented with dietary high-linoleate safflower seeds. J Anim Sci 84(9):2399-2405

Nakamura MT, Nara TY (2004) Structure, function, and dietary regulation of delta 6, delta 5, and delta 9 desaturases. Annu Rev Nutr 24:345-376

Ntambi JM (1999) Regulation of stearoyl-CoA desaturase by polyunsaturated fatty acids and cholesterol. J Lipid Res 40(9):1549-1558

Ntambi JM, Buhrow SA, Kaestner KH, Christy RJ, Sibley E, Kelly TJJ, Lane MD (1988) Differentiation-induced gene expression in 3T3-L1 preadipocytes. Characterization of a differentially expressed gene encoding stearoyl- CoA desaturase. J Biol Chem 263(33):17291-17300

Ntambi JM, Miyazaki M, Dobrzyn A (2004) Regulation of stearoyl-CoA desaturase expression. Lipids 39(11):1061-1065

Ollier S, Leroux C, de la Foye A, Bernard L, Rouel J, Chilliard Y (2009) Whole intact rapeseeds or sunflower oil in high-forage or high-concentrate diets affects milk yield, milk composition, and mammary gene expression profile in goats. J Dairy Sci 92(11):5544-5560

Oshino N, Sato R (1972) The dietary control of the microsomal stearyl CoA desaturation enzyme system in rat liver. Arch Biochem Biophys 149(2):369-377

Palmquist DL, Lock AL, Shingfield KJ, Bauman DE (2005) Biosynthesis of conjugated linoleic acid in ruminants and humans. In: Taylor SL (ed) Advances in food and nutrition research. Elsevier, San Diego, CA, pp 179-217

Parodi PW (1982) Positional distribution of fatty acids in the triglyceride classes of milk fat. J Dairy Res 49(1):73-80

Parodi PW (2005) Dairy product consumption and the risk of breast cancer. J Am Coll Nutr 24(6 Suppl):556S-568S

Pauciullo A, Cosenza G, Steri R, Coletta A, La Battaglia A, Di Berardino D, Macciotta NPP, Ramunno L (2012) A single nucleotide polymorphism in the promoter region of river buffalo stearoyl CoA desaturase gene (SCD) is associated with milk yield. J Dairy Res 79(04):429-435 
Perfield JW, Delmonte P, Lock AL, Yurawecz MP, Bauman DE (2006) Trans-10, trans-12 conjugated linoleic acid does not affect milk fat yield but reduces delta9-desaturase index in dairy cows. J Dairy Sci 89(7):2559-2566

Perfield JW, Lock AL, Griinari JM, Sæbø A, Delmonte P, Dwyer DA, Bauman DE (2007) Trans-9, cis-11 conjugated linoleic acid reduces milk fat synthesis in lactating dairy cows. J Dairy Sci 90(5):2211-2218

Peterson DG, Matitashvili EA, Bauman DE (2003) Diet-induced milk fat depression in dairy cows results in increased trans-10, cis-12 CLA in milk fat and coordinate suppression of mRNA abundance for mammary enzymes involved in milk fat synthesis. J Nutr 133(10):3098-3102

Peterson DG, Matitashvili EA, Bauman DE (2004) The inhibitory effect of trans-10, cis-12 CLA on lipid synthesis in bovine mammary epithelial cells involves reduced proteolytic activation of the transcription factor SREBP-1. J Nutr 134(10):2523-2527

Piperova LS, Teter BB, Bruckental I, Sampugna J, Mills SE, Yurawecz MP, Fritsche J, Ku K, Erdman RA (2000) Mammary lipogenic enzyme activity, trans fatty acids and conjugated linoleic acids are altered in lactating dairy cows fed a milk fat-depressing diet. J Nutr 130(10):2568-2574

Qiu X, Eastridge ML, Firkins JL (2004) Effects of dry matter intake, addition of buffer, and source of fat on duodenal flow and concentration of conjugated linoleic acid and trans-11 C18:1 in milk. J Dairy Sci 87(12):4278-4286

Rincon G, Islas-Trejo A, Castillo AR, Bauman DE, German BJ, Medrano JF (2012) Polymorphisms in genes in the SREBP1 signalling pathway and SCD are associated with milk fatty acid composition in Holstein cattle. J Dairy Res 79(01):66-75

Roy A, Ferlay A, Shingfield KJ, Chilliard Y (2006) Examination of the persistency of milk fatty acid composition responses to plant oils in cows given different basal diets, with particular emphasis on trans-C18:1 fatty acids and isomers of conjugated linoleic acid. Anim Sci 82:479-492

Sæbø A, Sæbø PC, Griinari JM, Shingfield KJ (2005) Effect of abomasal infusions of geometric isomers of 10, 12 conjugated synthesis linoleic acid on milk fat in dairy cows. Lipids $40(8)$ : $823-832$

Sampath H, Ntambi JM (2005) Polyunsaturated fatty acid regulation of genes of lipid metabolism. Annu Rev Nutr 25:317-340

Sessler AM, Kaur N, Palta JP, Ntambi JM (1996) Regulation of stearoyl-CoA desaturase 1 mRNA stability by polyunsaturated fatty acids in 3T3-L1 adipocytes. J Biol Chem 271(47): 29854-29858

Schennink A, Heck JML, Bovenhuis H, Visker MHPW, van Valenberg HJF, van Arendonk JAM (2008) Milk fatty acid unsaturation: genetic parameters and effects of stearoyl-CoA desaturase (SCD1) and acyl CoA: diacylglycerol acyltransferase 1 (DGAT1). J Dairy Sci 91(5): 2135-2143

Shingfield KJ, Ahvenjarvi S, Toivonen V, Vanhatalo A, Huhtanen P (2007) Transfer of absorbed cis-9, trans-11 conjugated linoleic acid into milk is biologically more efficient than endogenous synthesis from absorbed vaccenic acid in lactating cows. J Nutr 137(5):1154-1160

Shingfield KJ, Arola A, Ahvenjarvi S, Vanhatalo A, Toivonen V, Griinari JM, Huhtanen P (2008a) Ruminal infusions of cobalt-EDTA reduce mammary delta 9-desaturase index and alter milk fatty acid composition in lactating cows. J Nutr 138(4):710-717

Shingfield KJ, Chilliard Y, Toivonen V, Kairenius P, Givens DI (2008b) Trans fatty acids and bioactive lipids in ruminant milk. Adv Exp Med Biol 606:3-65

Shingfield KJ, Bernard L, Leroux C, Chilliard Y (2010) Role of trans fatty acids in the nutritional regulation of mammary lipogenesis in ruminants. Animal 4(7):1140-1166

Shingfield KJ, Bonnet M, Scollan ND (2013) Recent developments in altering the fatty acid composition of ruminant-derived foods. Animal 7(Supplements1):132-162

Shingfield KJ, Rouel J, Chilliard Y (2009) Effect of calcium salts of a mixture of conjugated linoleic acids containing trans-10, cis-12 in the diet on milk fat synthesis in goats. Br J Nutr 101(7):1006-1019 
Shingfield KJ, Toivonen V, Vanhatalo A, Huhtanen P, Griinari JM (2006) Short communication: indigestible markers reduce the mammary delta9-desaturase index and alter the milk fatty acid composition in cows. J Dairy Sci 89(8):3006-3010

Stoop WM, Bovenhuis H, Heck JML, van Arendonk JAM (2009) Effect of lactation stage and energy status on milk fat composition of Holstein-Friesian cows. J Dairy Sci 92(4):1469-1478

Taugbøl O, Karlengen IJ, Bolstad T, Aastveit AH, Harstad OM (2008) Cobalt supplied per os reduces the mammary \{delta\}9-desaturase index of bovine milk. J Anim Sci 86(11):3062-3068

Taugbøl O, Karlengen IJ, Salbu B, Aastveit AH, Harstad OM (2010) Intravenous injections of cobalt reduce fatty acid desaturation products in milk and blood of lactating cows. J Anim Physiol Anim Nutr 94(5):635-640

Thiede MA, Strittmatter P (1985) The induction and characterization of rat liver stearyl-CoA desaturase mRNA. J Biol Chem 260(27):14459-14463

Timmen H, Patton S (1988) Milk fat globules: fatty acid composition, size and in vivo regulation of fat liquidity. Lipids 23(7):685-689

Toral PG, Bernard L, Chilliard Y, Glasser F (2013a) Diet-induced variations in milk fatty acid composition have minor effects on the estimated melting point of milk fat in cows, goats, and ewes: insights from a meta-analysis. J Dairy Sci 96:1232-1236

Toral PG, Bernard L, Delavaud C, Gruffat D, Leroux C, Chilliard Y (2013b) Effects of fish oil and additional starch on tissue fatty acid profile and lipogenic gene mRNA abundance in lactating goats fed a diet containing sunflower-seed oil. Animal 7(6):948-956

Vakalopoulou E, Schaack J, Shenk T (1991) A 32-kilodalton protein binds to AU-rich domains in the $3^{\prime}$ untranslated regions of rapidly degraded mRNAs. Mol Cell Biol 11(6):3355-3364

Wahle KWJ, Heys SD, Rotondo D (2004) Conjugated linoleic acids: are they beneficial or detrimental to health? Prog Lipid Res 43(6):553-587

Wang W, Luo J, Zhong Y, Lin XZ, Shi HB, Zhu JJ, Li J, Sun YT, Zhao WS (2012) Goat liver X receptor alpha, molecular cloning, functional characterization and regulating fatty acid synthesis in epithelial cells of goat mammary glands. Gene 505(1):114-120

Wang J, Yu L, Schmidt RE, Su C, Huang X, Gould K, Cao G (2005) Characterization of HSCD5, a novel human stearoyl-CoA desaturase unique to primates. Biochem Biophys Res Commun 332(3):735-742

Ward RJ, Travers MT, Richards SE, Vernon RG, Salter AM, Buttery PJ, Barber MC (1998) Stearoyl-CoA desaturase mRNA is transcribed from a single gene in the ovine genome. Biochim Biophys Acta 1391(2):145-156

Yonezawa T, Haga S, Kobayashi Y, Katoh K, Obara Y (2008) Regulation of hormone-sensitive lipase expression by saturated fatty acids and hormones in bovine mammary epithelial cells. Biochem Biophys Res Commun 376(1):36-39

Zhang L, Ge L, Parimoo S, Stenn K, Prouty SM (1999) Human stearoyl-CoA desaturase: alternative transcripts generated from a single gene by usage of tandem polyadenylation sites. Biochem J 340(Pt 1):255-264

Zheng Y, Prouty SM, Harmon A, Sundberg JP, Stenn KS, Parimoo S (2001) Scd3-a novel gene of the stearoyl-CoA desaturase family with restricted expression in skin. Genomics 71(2): $182-191$

Zidi A, Fernández-Cabanás VM, Urrutia B, Carrizosa J, Polvillo O, González-Redondo P, Jordana J, Gallardo D, Amills M, Serradilla JM (2010) Association between the polymorphism of the goat stearoyl-CoA desaturase 1 (SCD1) gene and milk fatty acid composition in MurcianoGranadina goats. J Dairy Sci 93(9):4332-4339 